\title{
Effects of PVA coated nanoparticles on human immune cells
}

\author{
Cindy Strehl ${ }^{1,2}$ \\ Timo Gaber ${ }^{1-3}$ \\ Lionel Maurizi ${ }^{4}$ \\ Martin Hahne ${ }^{1,2}$ \\ Roman Rauch ${ }^{1,2}$ \\ Paula Hoff ${ }^{-3}$ \\ Thomas Häupl' \\ Margarethe Hofmann- \\ Amtenbrink $^{5}$ \\ A Robin Poole 6 \\ Heinrich Hofmann ${ }^{4}$ \\ Frank Buttgereit ${ }^{1-3}$ \\ 'Department of Rheumatology \\ and Clinical Immunology, Charité \\ Universitätsmedizin Berlin, Berlin, \\ Germany; ${ }^{2}$ German Rheumatism \\ Research Centre (DRFZ), Berlin, \\ Germany; ${ }^{3}$ Berlin-Brandenburg Center \\ for Regenerative Therapies (BCRT), \\ Berlin, Germany; ${ }^{4}$ Powder Technology \\ Laboratory, Ecole Polytechnique \\ Federale de Lausanne (EPFL), \\ Lausanne, Switzerland; ${ }^{5}$ MatSearch \\ Consulting Hofmann, Pully-Lausanne, \\ Switzerland; ${ }^{6}$ Department of Surgery, \\ McGill University, Montreal, QC, \\ Canada
}

This article was published in the following Dove Press journal: International Journal of Nanomedicine 8 May 2015

Number of times this article has been viewed

\begin{abstract}
Nanotechnology provides new opportunities in human medicine, mainly for diagnostic and therapeutic purposes. The autoimmune disease rheumatoid arthritis (RA) is often diagnosed after irreversible joint structural damage has occurred. There is an urgent need for a very early diagnosis of RA, which can be achieved by more sensitive imaging methods. Superparamagnetic iron oxide nanoparticles (SPION) are already used in medicine and therefore represent a promising tool for early diagnosis of RA. The focus of our work was to investigate any potentially negative effects resulting from the interactions of newly developed amino-functionalized amino-polyvinyl alcohol coated (a-PVA) SPION (a-PVA-SPION), that are used for imaging, with human immune cells. We analyzed the influence of a-PVA-SPION with regard to cell survival and cell activation in human whole blood in general, and in human monocytes and macrophages representative of professional phagocytes, using flow cytometry, multiplex suspension array, and transmission electron microscopy. We found no effect of a-PVA-SPION on the viability of human immune cells, but cytokine secretion was affected. We further demonstrated that the percentage of viable macrophages increased on exposure to a-PVA-SPION. This effect was even stronger when a-PVA-SPION were added very early in the differentiation process. Additionally, transmission electron microscopy analysis revealed that both monocytes and macrophages are able to endocytose a-PVA-SPION. Our findings demonstrate an interaction between human immune cells and a-PVA-SPION which needs to be taken into account when considering the use of a-PVA-SPION in human medicine.
\end{abstract}

Keywords: nanoparticle, cell viability, cytokine, monocyte, macrophage

\section{Introduction}

Rheumatoid arthritis (RA) is a chronic, systemic, inflammatory autoimmune disease of connective tissues, which mostly affects synovial joints. The inflammatory process leads to a local release of pro-inflammatory cytokines, including TNF $\alpha$ and IL-1, that activate enzymes involved in the degradation of articular cartilage and subchondral bone. Other tissues and organs may also be harmed as a result of the disease. ${ }^{1-9}$

Between $0.5 \%$ and $1 \%$ of the human population within industrialized countries suffer from RA (three times as many women as men), with the average age of disease onset between 40 and 50 years. ${ }^{10}$ The causes of RA are not completely clarified, but the development of the disorder seems to result from a combination of genetic factors and environmental triggers. ${ }^{11-14}$ The typical clinical signs of RA (symmetric joint swellings, morning stiffness, pain, and asthenia) are important for diagnosing this disease. Additionally, imaging techniques like X-ray, ultrasound and magnetic resonance imaging (MRI) as well as laboratory tests (such as inflammatory markers, rheumatoid factors, and anti-citrullinated protein antibodies) complete the diagnosis and permit surveillance of disease activity, progress and therapy success. ${ }^{15-18}$ There is no cure for RA, but the treatment can improve symptoms and quality of life, and can
Correspondence: Cindy Strehl Department of Rheumatology and Clinical Immunology, Charité University Hospital, Charitéplatz I, I0II7 Berlin,

Germany

Tel +4930450513364

Fax +4930450513917

Email cindy.strehl@charite.de
International Journal of Nanomedicine 20 I 5: 10 3429-3445 (c) (i) (5) 2015 Strehl et al. This work is published by Dove Medical Press Limited, and licensed under Creative Commons Attribution - Non Commercial (unported, v3.0) License. The full terms of the License are available at http://creativecommons.org/licenses/by-nc/3.0/. Non-commercial uses of the work are permitted without any further permission from Dove Medical Press Limited, provided the work is properly attributed. Permissions beyond the scope of the License are administered by Dove Medical Press Limited. Information on
how to request permission may be found at: http://www.dovepress.com/permissions.php 
reduce or even stop the progress of the disease. Typically, disease-modifying anti-rheumatic drugs, biological agents, glucocorticoids and non-steroidal anti-inflammatory drugs are used for treatment. ${ }^{5,19-21}$ Nevertheless, some patients do not respond adequately to the prescribed drug, requiring 3 months of treatment before a lack of response becomes apparent. Only after this period of time has elapsed can treatment strategy be modified, with further progress of the disease potentially occurring due to the loss of this treatment time. Additionally, all treatment strategies involve some side effects. ${ }^{8,9,22-24}$

It has been shown that the earlier patients with RA are treated the more effective is the treatment. ${ }^{25,26}$ Thus there is an urgent need for a very early diagnosis of RA in order to enable earlier treatment and to reduce or even to stop the progress of the disease. Furthermore, an early diagnosis can prevent joint damage, thereby lowering the additional therapeutic and disability costs which arise from reduced work capacity of the patients: nearly $30 \%$ of patients give up work within 1 year as a result of their condition and almost $60 \%$ within 6 years of diagnosis. ${ }^{27}$ Thus, there is a considerable need for highly sensitive and specific diagnostic tools to detect early disease. Such tools could also facilitate further drug development and enable health professionals to distinguish between responders and non-responders before and after onset of therapy.

One promising approach to generate such a tool is the use of nanotechnology employing superparamagnetic iron oxide nanoparticles (SPION). These have been intensively investigated over the last 20 years for various in vitro and in vivo biomedical applications. ${ }^{28,29}$ Promising studies have been performed with SPION as contrast enhancers for MRI. ${ }^{30-35}$ Currently, SPION are used as contrast agents for liver function. For example, the product Feridex ${ }^{\circledR}$ was approved by the US Food and Drug Administration (FDA) in 1996. ${ }^{36,37}$ MRI has been used for many years in cross-sectional and observational studies in RA and in controlled clinical trials to identify early cartilage loss in osteoarthritis and RA. ${ }^{38,39}$ This method is also useful to assess and monitor disease activity in order to detect and follow pre-erosive features of RA (such as synovitis, bone marrow edema or osteitis, and tendon and ligament abnormalities) that other methods like radiography cannot detect. ${ }^{17,40,41}$ Detection of early cartilage and bone erosion is essential so that therapy can be initiated as early as possible following reliable diagnosis. ${ }^{42}$

The contrast agents that are normally used in MRI are based on either particles with paramagnetic (like gadolinium) or superparamagnetic behavior (like iron oxide nanoparticles). ${ }^{43}$ As a gold standard for synovial imaging, gadolinium-enhanced MRI is used for the detection of synovial hypervascularity of arthritic joints and early cartilage degeneration without structural change. Gadoliniumenhanced MRI has limitations, as the synovial contrast enhancement is nonspecific and the enhancement patterns of normal and inflamed joints often overlap. The need for selective tissue-, cell-, and receptor-specific contrast agents is obvious since they should i) provide much improved detection of earlier degenerative events and responses to therapy, ii) better define and characterize the inflammatory and degradative processes, and iii) be more efficient ie, at lower doses. Targeted SPION offer a significant opportunity for improved diagnostic MRI imaging. ${ }^{44}$

Similar to gadolinium, which is highly toxic as an element so needs to be given as a complex, iron oxide nanoparticles also need to be covered by a coating to guarantee safe application. The size of the particles and their coating characteristics determine pharmacokinetics, biodistribution and specificity, and possibly toxicity. SPION-based contrast agents have been developed as liver specific contrast agents because of their specificity for reticuloendothelial cells. Depending on their size, SPION of a larger hydrodynamic size are preferentially taken up by liver Kupffer cells. In contrast, smaller sizes of SPION are mostly taken up by macrophages of the lymph nodes, or are directed to liver, lung, or spleen, or may cross the blood-brain barrier. ${ }^{45}$ SPION are mostly taken up intracellularly by endocytosis. ${ }^{46-48}$ Various studies show that dextran coated SPION uptake is driven by scavenger receptors, which are then metabolized in the lysosomes into ferritin or hemoglobin and as a result of this become part of the normal blood pool. ${ }^{43,47,49}$

SPION coated with vinyl-alcohol/vinyl-amine copolymer (amino-polyvinyl alcohol [a-PVA]), as used in our study, are taken up in vitro by synovial cells, chondrocytes, and osteoblasts after a 2 hour incubation. ${ }^{50}$ Furthermore, a very recent study revealed that amino-polyvinyl alcohol coated superparamagnetic iron oxide nanoparticles (a-PVA-SPION) were also taken up by human mesenchymal stromal cells (MSCs), which are of considerable interest in cell-based therapies. The study also demonstrated that these high contrast particles are non-toxic and suitable for MSC visualization in MRI, in vitro as well as in vivo, in rats. ${ }^{51}$

The colloidal stability and, therefore, cell uptake and cytotoxicity are strongly influenced by the composition of the SPION polymer coat (eg, polyvinyl alcohol, vinyl alcohol/vinyl amine copolymer, or polyethylenimine). Although these polymer-coated SPION are stable in water 
and phosphate buffered saline (PBS), the choice of medium largely influences the cellular uptake of these particles. ${ }^{52,53}$

Although various industrially produced SPION are being investigated in clinical trials and seem to produce very low side effects, the potential for cytotoxicity of these particles is still an important issue of debate. Investigation of the immune responses of dendritic cells to PVA coated SPION show a certain degree of immunomodulation. ${ }^{54}$ Such properties - but also the impact of SPION on cell proliferation and cell functionality - depend upon the physicochemical properties of the particle surfaces and the cells used for such tests. ${ }^{55,56}$

Therefore, we have investigated the interactions of amino functionalized SPION, developed for early diagnosis in arthritis, with different human immune cells obtained from patients suffering from RA and from healthy donors (HD). We investigated potential effects on specific immune cell viability as well as cytokine secretion as an indicator of immune cell activation.

\section{Materials and methods Materials}

In this study we used a-PVA-SPION which were synthesized and characterized following a protocol previously described. ${ }^{51}$ The mean diameter of the magnetic cores $\left(\mathrm{d}_{\text {core }}\right.$ in $\left.\mathrm{nm}\right)$ of the a-PVA-SPION was determined by counting 400 diameters observed in transmission electron microscopy (TEM; CM12 from Philips Electron Optics, Zürich, Switzerland). Hydrodynamic size $\left(\mathrm{d}_{\mathrm{H}}\right.$ in $\left.\mathrm{nm}\right)$ and Zeta potential ( $\mathrm{Z}$ potential in $\mathrm{mV}$ ) were measured at around $\mathrm{pH} 7$ by dynamic laser scattering using a Malvern NanoZS (Nanosizer 7.2 software) using the theoretical refractive index of 2.42 of magnetite. ${ }^{57}$ The saturation magnetization (Sat mag in emu/g) was obtained from freeze dried powder of SPION before PVA coatings using a superconducting quantum interference device. ${ }^{58}$

\section{Antibodies and reagents}

Lipopolysaccharide (LPS), lectin from Phaseolus vulgaris (PHA), Brefeldin A, Saponin, and carboxyfluorescein diacetate N-succinimidyl ester (CFSE) were from Sigma-Aldrich Co., St Louis, MO, USA. Paraformaldehyde was from Carl Roth $\mathrm{GmbH}+\mathrm{Co}$. KG (Karlsruhe, Germany). Recombinant human macrophage colony stimulating factor (rhM-CSF) was from ImmunoTools GmbH (Friesoythe, Germany).

For flow cytometry, Privigen ${ }^{\circledR}$ human immunoglobulin from CSL Bhering, (King of Prussia, PA, USA) was used. Anti-human-IL1 $\beta$-PE, anti-human-CD3-Pacific-blue, antihuman-CD14-APC-Cy7, anti-human-CD19-PE-Cy7, and
Annexin V/7AAD apoptosis kit were from BD Biosciences (San Jose, CA, USA) and anti-human-CD15-APC was from Miltenyi Biotech GmbH (Bergisch Gladbach, Germany).

\section{Whole blood survival analysis, sample preparation, and stimulation}

Venous blood (obtained from RA patients or HD) was collected in heparinized tubes. All patients met the American Rheumatism Association criteria (1987) for RA. ${ }^{59}$ The characteristics of RA patients are summarized in Table S1. The study protocol was approved by the responsible local administrative body and ethics committee. RA patients as well as HD provided written informed consent before enrollment.

Immediately after retrieval of the blood samples, $100 \mu \mathrm{L}$ of whole blood was diluted with $100 \mu \mathrm{L}$ Roswell Park Memorial Institute (RPMI) 1640 culture medium (Thermo Fisher Scientific, Waltham, MA, USA) supplemented with $100 \mathrm{U} / \mathrm{mL}$ penicillinG, $100 \mu \mathrm{g} / \mathrm{mL}$ streptomycin (both from PAA Laboratories) and $50 \mu \mathrm{M} \beta$-mercaptoethanol (SigmaAldrich Co.) in deep-well-plates (Sarstedt AG \& Co., Nuembrecht, Germany). Cells were stimulated with LPS $(1 \mu \mathrm{g} / \mathrm{mL})$, PHA $(5 \mu \mathrm{g} / \mathrm{mL})$, a-PVA-SPION (1 $\mu \mathrm{g} / \mathrm{mL}, 10 \mu \mathrm{g} / \mathrm{mL}$, $100 \mu \mathrm{g} / \mathrm{mL}, 1,000 \mu \mathrm{g} / \mathrm{mL}$ ) or left untreated and incubated for 20 hours in a humidified incubator at $37^{\circ} \mathrm{C}\left(18 \% \mathrm{O}_{2} / 5 \%\right.$ $\mathrm{CO}_{2}$ ). Afterwards, supernatants were collected, immediately frozen, and stored at $-80^{\circ} \mathrm{C}$ for cytokine secretion analysis and cells were prepared for flow cytometry (see section Flow cytometric analysis). For intracellular IL1 $\beta$ analysis, secretion was blocked by adding $10 \mu \mathrm{g} / \mathrm{mL}$ Brefeldin A followed by an additional incubation for 3 hours at $37^{\circ} \mathrm{C}$.

\section{Quantification of secreted cytokines}

Secreted cytokines were quantified by Bio-Plex ${ }^{\circledR}$ Pro Cytokine 27-Plex Panel Human Group I on a Bio-Plex ${ }^{\circledR} 200$ system with high-throughput fluidics (all Bio-Rad Laboratories Inc., Hercules, CA, USA). Intracellular IL1 $\beta$ concentration was determined via flow cytometry as described below.

\section{Isolation and stimulation of human $\mathrm{CDI} 4^{+}$monocytes}

Peripheral blood mononuclear cells were isolated from leukocyte apheresis filters of healthy blood donors by density gradient centrifugation using the Ficoll-Paque ${ }^{\mathrm{TM}}$ Plus technique (Amersham Biosciences Europe GmbH, Freiburg, Germany). CD14 positive monocytes were enriched up to $99 \%$ purity and $>95 \%$ viability (data not shown) by MACS ${ }^{\circledR}$ Technology (Miltenyi Biotec $\mathrm{GmbH}$ ) using anti-human CD14 conjugated magnetic beads as described by the manufacturer. 
Fresh isolated CD14 positive monocytes were labeled with $0.3125 \mathrm{mM}$ CFSE for 3.5 minutes at room temperature (RT) and cultured at $2 \times 10^{6}$ cells $/ \mathrm{mL}$ in RPMI 1640 culture medium supplemented with $10 \%(\mathrm{v} / \mathrm{v})$ heatinactivated fetal calf serum (FCS) (Sigma-Aldrich Co.), 100 units/mL penicillinG, $100 \mu \mathrm{g} / \mathrm{mL}$ streptomycin, and $50 \mu \mathrm{M} \beta$-mercaptoethanol for 20 hours in 24-well cell culture plates. Cells were stimulated with LPS ( $1 \mu \mathrm{g} / \mathrm{mL})$, a-PVASPION ( $1 \mu \mathrm{g} / \mathrm{mL}, 10 \mu \mathrm{g} / \mathrm{mL}, 100 \mu \mathrm{g} / \mathrm{mL}$, and 1,000 $\mu \mathrm{g} /$ $\mathrm{mL}$ ) or left untreated for 20 hours in a humidified incubator at $37^{\circ} \mathrm{C}\left(18 \% \mathrm{O}_{2} / 5 \% \mathrm{CO}_{2}\right)$. Afterwards, cells were detached with Accutase (PAA Laboratories GmbH, Cölbe, Germany) and further prepared for flow cytometry (see section Flow cytometric analysis).

\section{Generation of monocyte-derived macrophages (MDMs)}

Freshly isolated CD14 positive monocytes (see section Isolation and stimulation of human $C D 14^{+}$monocytes) as $6 \mathrm{~mL}$ of $2 \times 10^{6}$ cells $/ \mathrm{mL}$ PBS were added to a covered $10 \mathrm{~cm}$ diameter Petri dish. Cells were incubated for 2 hours at $37^{\circ} \mathrm{C}$ ( $\left.18 \% \mathrm{O}_{2} / 5 \% \mathrm{CO}_{2}\right)$. Afterwards, supernatants were carefully removed and $6 \mathrm{~mL}$ fresh RPMI 1640 medium containing $50 \mathrm{ng}$ rhM-CSF was added to the adherent cells. After 24 and 72 hours at $37^{\circ} \mathrm{C}\left(18 \% \mathrm{O}_{2} / 5 \% \mathrm{CO}_{2}\right)$ medium was refreshed by adding $6 \mathrm{~mL}$ of RPMI 1640 containing $50 \mathrm{ng}$ rhM-CSF. After a total of 6 days incubation, the differentiated MDMs were detached with Accutase and the remaining adherent cells were removed with a cell scraper.

\section{Stimulation of monocytes/MDMs with a-PVA-SPION}

Two different approaches have been followed: I) MDMs were labeled with $0.3125 \mathrm{mM}$ CFSE for 3.5 minutes at RT and $5 \times 10^{4}$ cells/200 $\mu \mathrm{L}$ RPMI 1640 medium/well were incubated for 20 hours in 48-well cell culture plates. MDMs were stimulated with LPS ( $1 \mu \mathrm{g} / \mathrm{mL})$, a-PVA-SPION $(1 \mu \mathrm{g} / \mathrm{mL}$, $10 \mu \mathrm{g} / \mathrm{mL}, 100 \mu \mathrm{g} / \mathrm{mL}$, and $1,000 \mu \mathrm{g} / \mathrm{mL})$ or left untreated in a humidified incubator at $37^{\circ} \mathrm{C}\left(18 \% \mathrm{O}_{2} / 5 \% \mathrm{CO}_{2}\right)$ and afterwards prepared for flow cytometry (see section Flow cytometric analysis). II) Monocytes were labeled with $0.3125 \mathrm{mM}$ CFSE for 3.5 minutes at RT and $2 \times 10^{5}$ cells $/ 100$ $\mu \mathrm{L}$ PBS/well were incubated for 1 hour in 48 -well cell culture plates for attachment. Afterwards, the PBS-buffer was removed and $200 \mu \mathrm{L}$ RPMI 1640 medium containing $50 \mathrm{ng}$ rhM-CSF was added. The cells were stimulated with $1 \mu \mathrm{g} / \mathrm{mL}$ LPS or left untreated for 6 days. Stimulation with a-PVA-SPION during the differentiation process to
MDMs was performed as follows: a-PVA-SPION $(1 \mu \mathrm{g} / \mathrm{mL}$, $10 \mu \mathrm{g} / \mathrm{mL}, 100 \mu \mathrm{g} / \mathrm{mL}$, and $1,000 \mu \mathrm{g} / \mathrm{mL}$ ) were added at day zero within the first addition of RPMI 1640 medium containing $50 \mathrm{ng}$ rhM-CSF or 24 hours later, when refreshing the medium or 72 hours later, when refreshing the medium again. Addition of fresh medium was performed as described in the section Generation of monocyte-derived macrophages $(M D M s)$. Cells were incubated in a humidified incubator at $37^{\circ} \mathrm{C}\left(18 \% \mathrm{O}_{2} / 5 \% \mathrm{CO}_{2}\right)$ until MDMs could be harvested after 6 days and prepared for flow cytometry.

\section{Flow cytometric analysis}

Whole blood extracellular staining

After lysis of erythrocytes, with a solution of potassium

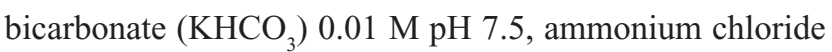
$\left(\mathrm{NH}_{4} \mathrm{Cl}\right) 0.155 \mathrm{M}$, ethylenediaminetetraacetic acid (EDTA) $0.1 \mathrm{mM}$, cells were washed with PBS and transferred to 96-well V-bottom assay plates. Non-specific binding was blocked by pre-incubation with human immunoglobulin $(5 \mathrm{mg} / \mathrm{mL})$ for 10 minutes at $4^{\circ} \mathrm{C}$. After washing the cells with PBS, an antibody-mix (anti-CD3, anti-CD14, anti-CD19, and anti-CD15) was added (all antibodies diluted 1/50 in PBS or $1 / 10$ when additionally stained intracellularly) and incubation was performed for 15 minutes at $4^{\circ} \mathrm{C}$ in the dark. Cells were washed twice and cells were analyzed within 1 hour by flow cytometry using the MACSQuant analyzer equipped with plate MACSQuant MiniSampler. The acquired data were analyzed using FlowJo 7.6.1 software. For the investigation of survival of positive cells for the surface markers (CD3, CD14, CD19 or CD15), Annexin V-PE/7-AAD staining was performed according to the manufacturer's instructions after cell washing (to determine apoptosis). After data acquisition by flow cytometry, these populations were analyzed for the percentage of Annexin V (apoptotic) or 7-AAD (dead) positive cells.

\section{Whole blood intracellular staining}

After extracellular antibody staining, cells were fixed with $2 \%$ paraformaldehyde and subsequently cell membranes were permeabilized by washing twice with $0.5 \%$ SaponinPBA (PBS/BSA/Acid). Non-specific binding was blocked with human immunoglobulin $(5 \mathrm{mg} / \mathrm{mL})$ for 10 minutes at RT. The washed (Saponin-PBA) cell pellets were resuspended in $10 \mu \mathrm{L}$ of undiluted anti-human-IL1 $\beta$-PE antibody and incubated for 15 minutes at RT in the dark. After two final washing steps cells were analyzed by flow cytometry using the MACSQuant analyzer equipped with plate MACSQuant MiniSampler. The acquired data were analyzed using FlowJo 
7.6.1 software, where positive cells for the according surface marker (CD3, CD14, CD19 or CD15) were selected and these populations were analyzed for the percentage and number of IL1 $\beta$ positive cells.

\section{Monocyte/MDM survival analysis}

After detachment of the cells with Accutase and cell scraper, Annexin V-PE/7-AAD staining was performed according to the manufacturer's instructions and cells were analyzed within 1 hour by flow cytometry using the MACSQuant analyzer equipped with plate MACSQuant MiniSampler.

\section{TEM analysis}

Human monocytes $\left(2 \times 10^{6}\right.$ cells $\left./ \mathrm{mL}\right)$ and MDMs $\left(1 \times 10^{6}\right.$ cells $\left./ \mathrm{mL}\right)$ were incubated for 24 hours with PVASPION $(1,000 \mu \mathrm{g} / \mathrm{mL})$ or left untreated. Cells were prepared for TEM analysis as previously described..$^{60}$ Ultrathin sections were analyzed using routine TEM (EM 906; Carl Zeiss AG Oberkochern, Germany) techniques; micrographs were prepared and further processed using Adobe Photoshop CS software.

\section{Statistical analysis}

Statistical tests for the flow cytometry were performed using Graph Pad Prism Software. Data are presented as box and whiskers, whiskers from minimum to maximum or mean with standard deviation of at least four independent experiments. Multiple comparisons were analyzed by one-way or two-way analysis of variance (ANOVA) as indicated with Bonferroni's multiple comparison post hoc tests for normally distributed data. Probability values of $P<0.05$ were considered to be statistically significant $(* * * P<0.001 ; * * P<0.01 ; * P<0.05)$.

\section{Results}

\section{Physicochemical characterizations of a-PVA-SPION}

The $\mathrm{d}_{\text {core }}$ of the a-PVA-SPION (Table 1) is approximately $7 \mathrm{~nm}$ which is small enough to have superparamagnetic properties confirmed by Sat mag of $54 \mathrm{emu} / \mathrm{g}$ and the absence of hysteresis. ${ }^{58,61}$ The hydrodynamic size of the a-PVA-SPION is approximately $30 \mathrm{~nm}$ at $\mathrm{pH} 7$ and the Zeta potential is approximately $22 \mathrm{mV}$ indicating the positive initial charges of these nanoparticles at physiological $\mathrm{pH}$.

\section{a-PVA-SPION do not affect the survival of human immune cells within whole blood}

We obtained venous blood from 19 patients with RA and $18 \mathrm{HD}$. To analyze the influence of a-PVA-SPION on human immune cells, we quantified the number of Annexin V (apoptotic) or 7AAD (dead) positive cells in combination with the cell specific extracellular markers (CD-antigens). For both RA (Figure 1A) and HD (Figure 1B), and for all cell types analyzed, we did not find any significant influence of a-PVA-SPION on apoptosis and viability. Furthermore, we found that $\mathrm{CD} 3$ positive $\mathrm{T}$ cells show the lowest apoptosis and necrosis rates as demonstrated by the low percentages of Annexin $\mathrm{V}$ and 7AAD positive cells (median values between $20 \%$ and $42 \%$ ) whereas CD19 positive B cells showed the highest percentages of apoptosis and necrosis within their cell population (median values of Annexin $\mathrm{V}$ and 7AAD positive cells between $52 \%$ and $78 \%$ ).

For RA patients (Figure 1A) we observed a non-significant a-PVA-SPION concentration-dependent increase in Annexin $\mathrm{V}$ positive CD14 monocytes (median value for a-PVASPION at $1 \mu \mathrm{g} / \mathrm{mL}=45.9 \%$ and at $1,000 \mu \mathrm{g} / \mathrm{mL}=68.2 \%$ ). This was not observed in HD (Figure 1B), where we found a minimal non-significant a-PVA-SPION concentration-dependent decrease of Annexin $\mathrm{V}$ positive $\mathrm{CD} 15$ granulocytes (median value for PVA-SPION at $1 \mu \mathrm{g} / \mathrm{mL}=60.5 \%$ and at $1,000 \mu \mathrm{g} / \mathrm{mL}=45.5 \%$ ).

\section{a-PVA-SPION trigger cytokine secretion by dose-dependent cell activation in whole blood}

From whole blood viability experiments, supernatants were collected prior to sample preparation for flow cytometry and secreted cytokines were analyzed using the Bio-Plex ${ }^{\circledR}$ Suspension array system. We examined supernatants from nine RA patients and four HD and found significantly increased secretion of the following cytokines in the presence of a-PVA-SPION (at $100 \mu \mathrm{g} / \mathrm{mL}$ ) when compared to the untreated control (Figure 2): RA patients - IL1 $\beta$, IL4, IL6, IL8, IL9, IFN- $\gamma$, MCP-1, MIP1a, MIP1b, and PDGF; HD - IL1 $\beta$, IL4, IL6, IL8, MIP1b, and RANTES. One example is given in Figure 2A:

Table I Physicochemical characterizations of a-PVA-SPION

\begin{tabular}{lllll}
\hline Nanoparticles & $\mathrm{d}_{\text {core }}(\mathrm{nm})$ & $\mathrm{d}_{\mathrm{H}}(\mathrm{nm})$ & $\mathbf{Z}_{\text {potential }(\mathrm{mV})}$ & Sat mag $(\mathrm{emu} / \mathrm{g})$ \\
\hline a-PVA-SPION & $7.2 \pm 2.5$ & $3 \mathrm{I} \pm 10$ & $22 \pm 6$ & 54 \\
\hline
\end{tabular}

Abbreviations: $d_{\text {core }}$, mean diameter of the magnetic cores; $d_{H}$, hydrodynamic diameter; $Z$ potential, Zeta potential; Sat mag, the saturation magnetization; a-PVA-SPION, amino-polyvinyl alcohol coated superparamagnetic iron oxide nanoparticles. 

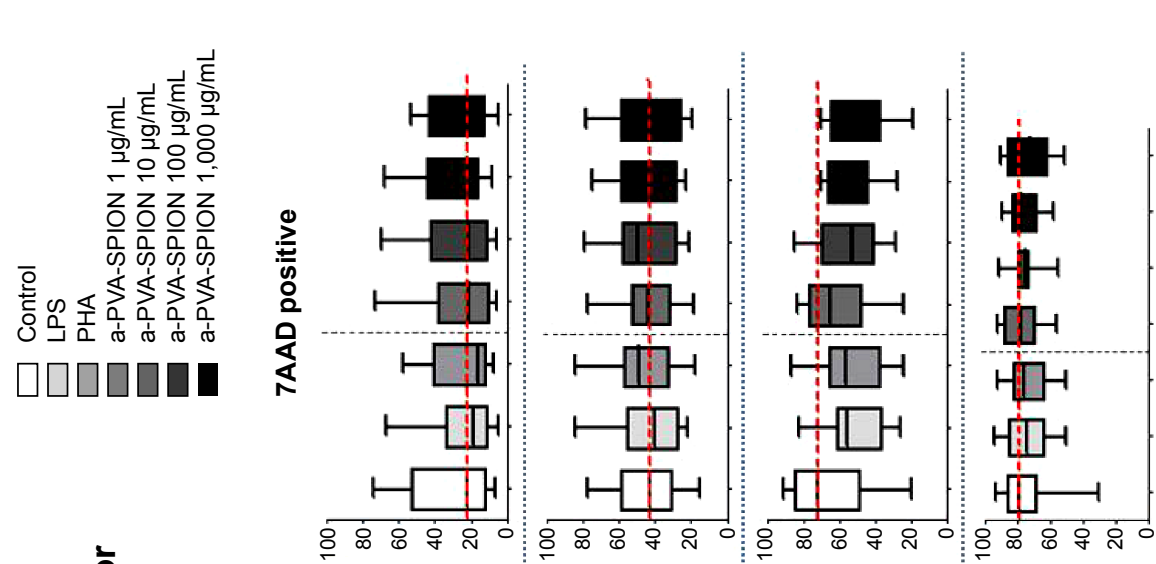

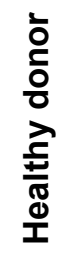
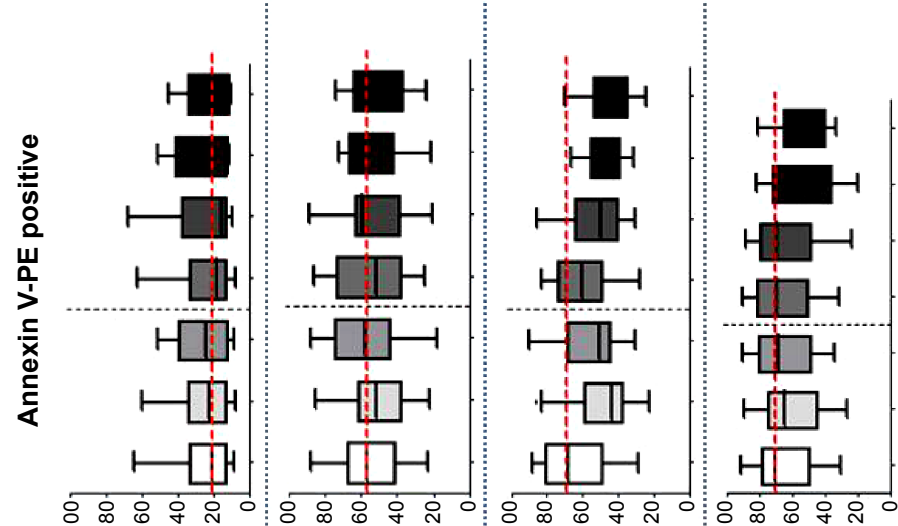

$\boldsymbol{m}$
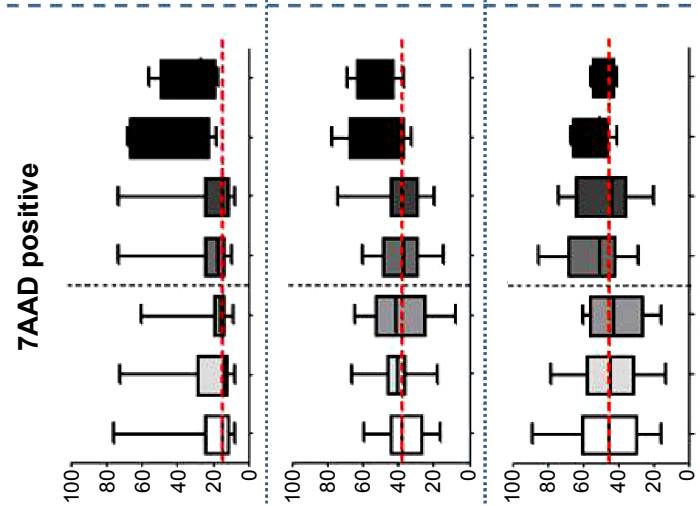

8.

$\llbracket$
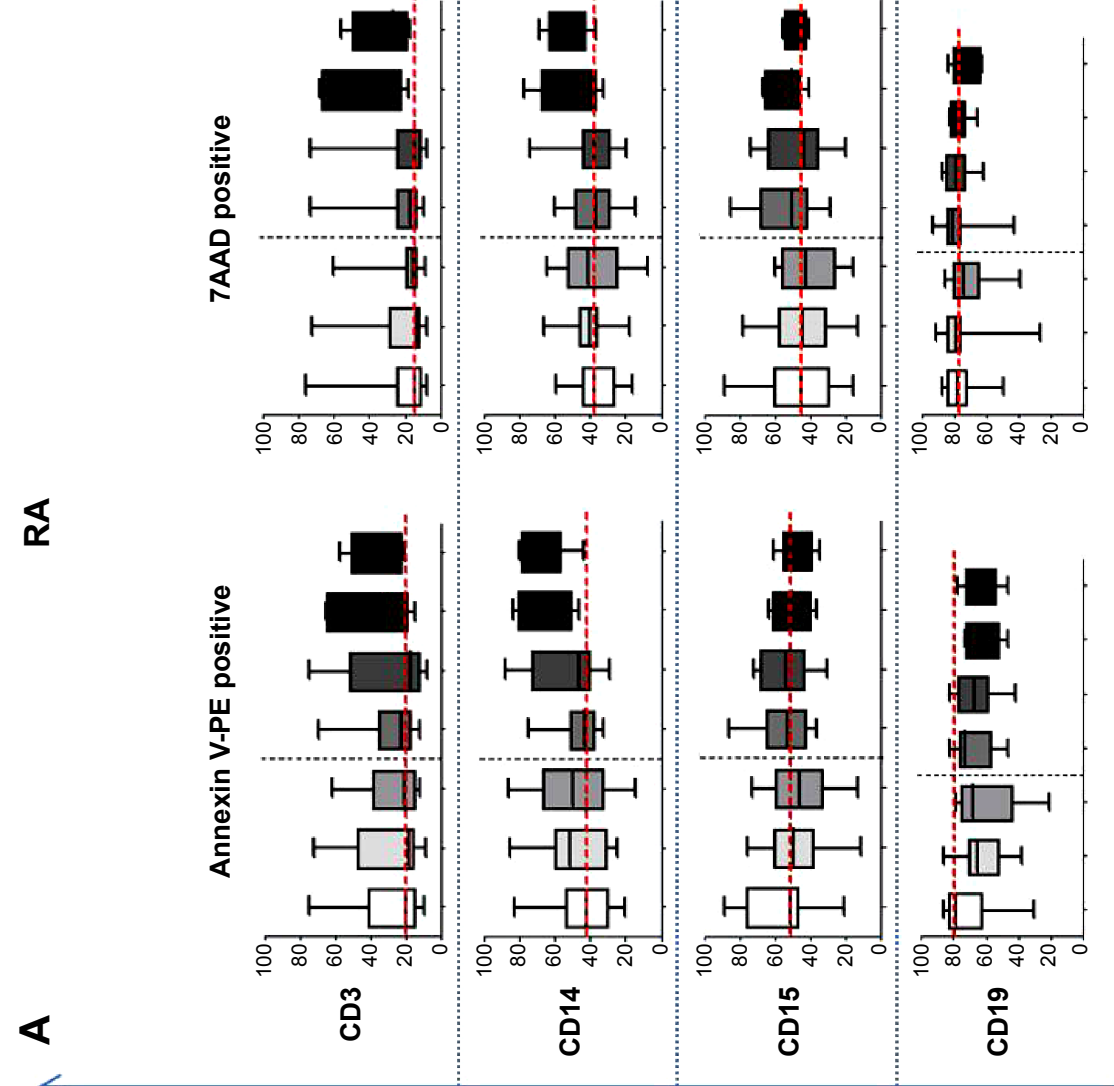

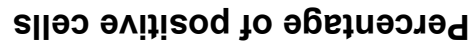

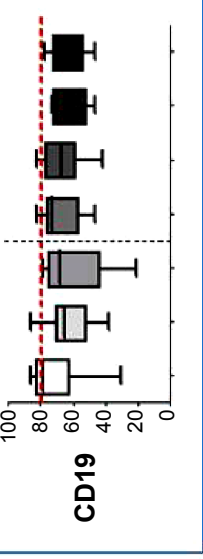

$\frac{1}{10}$
$\frac{0}{0}$

\section{을}

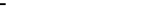

낭

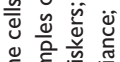

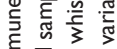

트은

要

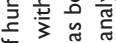

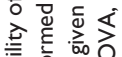

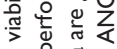

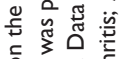

乙

은 要

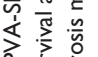

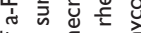

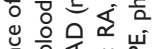

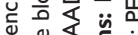

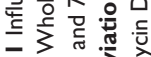

min 

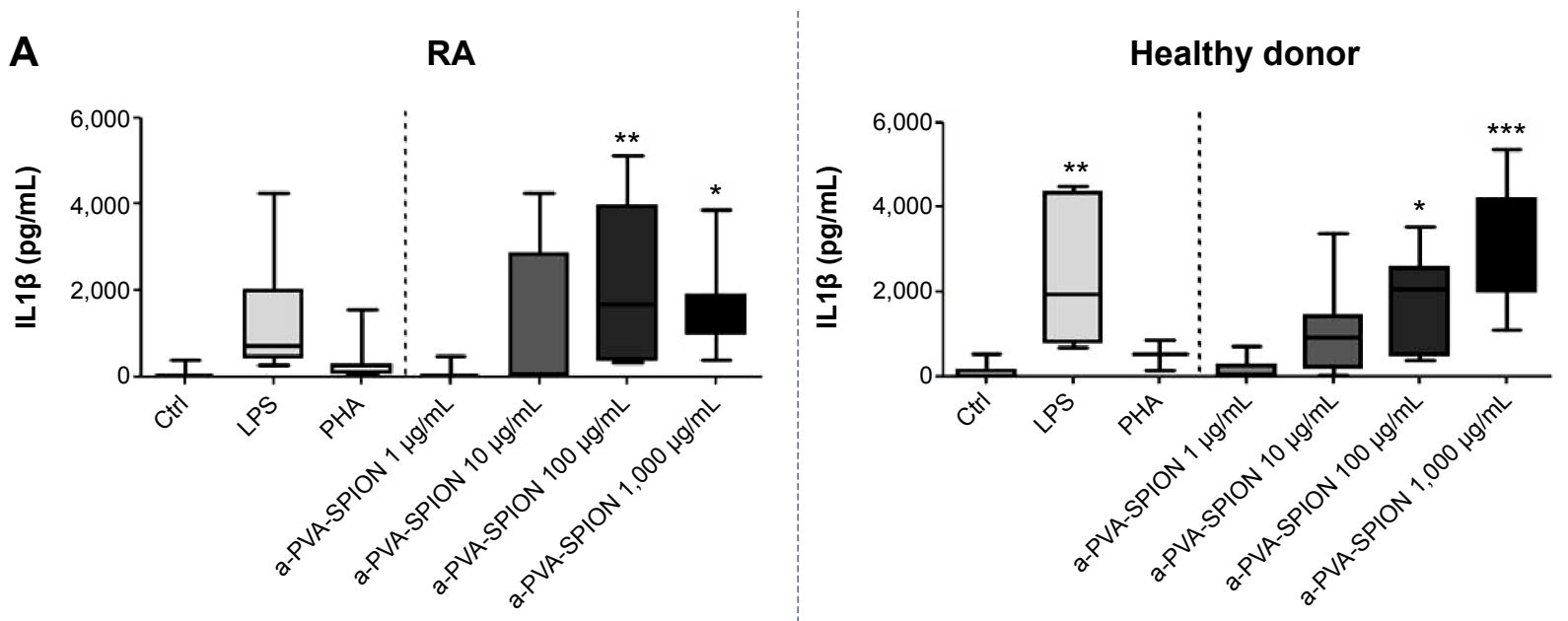

\section{B}

\begin{tabular}{|c|c|}
\hline Cytokine & RA \\
\hline IL1ra & $\rightarrow$ \\
\hline IL1 $\beta$ & 4 \\
\hline IL2 & nd \\
\hline IL4 & 4 \\
\hline IL5 & nd \\
\hline IL6 & 4 \\
\hline IL7 & nd \\
\hline IL8 & 4 \\
\hline IL9 & 4 \\
\hline IL10 & $\pi$ \\
\hline IL12 & $\rightarrow$ \\
\hline IL13 & nd \\
\hline IL15 & nd \\
\hline IL17 & $\rightarrow$ \\
\hline Eotaxin & $\rightarrow$ \\
\hline FGF basic & $\rightarrow$ \\
\hline G-CSF & $\pi$ \\
\hline GM-CSF & $\rightarrow$ \\
\hline $\mathrm{IFN}-\gamma$ & 4 \\
\hline MCP1 & 4 \\
\hline MIP1a & 4 \\
\hline MIP1b & 4 \\
\hline IP10 & $\rightarrow$ \\
\hline PDGF & 4 \\
\hline RANTES & $\rightarrow$ \\
\hline TNF $\alpha$ & $\rightarrow$ \\
\hline VEGF & $\rightarrow$ \\
\hline
\end{tabular}

Figure 2 Comparison of the influence of a-PVA-SPION on whole blood cytokine secretion by immune cells of RA patients and healthy donors.

Notes: Supernatants were collected from whole blood survival assays (blood samples obtained from patients with RA [ $n=9$, left] or healthy donors [ $\mathrm{n}=4$, right]). One example for ILI $\beta$ secretion is given in detail in (A), and a tabular overview for all measured cytokines is presented in (B). Red arrow: cytokines that were significantly increased at SPION concentration $100 \mu \mathrm{g} / \mathrm{mL}$ compared to untreated control; black arrow: cytokines significantly increased at any other SPION concentration than I00 $\mu \mathrm{g} / \mathrm{mL}$ compared to untreated control; green arrow: cytokines that remained unchanged; nd: not detectable; data are given as box and whiskers; whiskers represent minimum to maximum; one-way ANOVA: $* * * P<0.00 I ; * * P<0.01 ; * P<0.05$

Abbreviations: RA, rheumatoid arthritis; ANOVA, analysis of variance; Ctrl, control; LPS, lipopolysaccharide; PHA, Phaseolus vulgaris; HD, healthy donors; a-PVA-SPION, amino-polyvinyl alcohol coated superparamagnetic iron oxide nanoparticles.

unstimulated cells secrete IL1 $\beta$ at a median concentration of $55 \mathrm{pg} / \mathrm{mL}$ whereas 20 hours incubation with a-PVASPION led to median values of $67.2 \mathrm{pg} / \mathrm{mL}$ (at $1 \mu \mathrm{g} / \mathrm{mL}$ ), $1,075 \mathrm{pg} / \mathrm{mL}$ (at $10 \mu \mathrm{g} / \mathrm{mL}$ ), $2,076 \mathrm{pg} / \mathrm{mL}$ (at $100 \mu \mathrm{g} / \mathrm{mL}$ ), and $1,573 \mathrm{pg} / \mathrm{mL}$ (at $1,000 \mu \mathrm{g} / \mathrm{mL}$ ) in blood samples obtained from RA patients. For HD we found similar results: control cells secrete IL1 $\beta$ at median concentration of $96.3 \mathrm{pg} / \mathrm{mL}$ whereas a-PVA-SPION incubation resulted in IL1 $\beta$ median values of $155.4 \mathrm{pg} / \mathrm{mL}$ (at $1 \mu \mathrm{g} / \mathrm{mL}$ ), $1,105 \mathrm{pg} / \mathrm{mL}$ (at $10 \mu \mathrm{g} / \mathrm{mL}$ ), $1,860 \mathrm{pg} / \mathrm{mL}$ (at $100 \mu \mathrm{g} / \mathrm{mL}$ ), and 3,025 pg/mL (at $1,000 \mu \mathrm{g} / \mathrm{mL}$ ) (Figure 2A; Tables S2 and S3). The secretion of G-CSF was found to be significantly increased at 
$1,000 \mu \mathrm{g} / \mathrm{mL}$ of a-PVA-SPION for both, RA patients and healthy subjects, whereas IL10 was found to be significantly increased at $1,000 \mu \mathrm{g} / \mathrm{mL}$ of a-PVA-SPION in RA patients. All other cytokines were unaffected by a-PVA-SPION treatment (see Tables and Figure 2B; all median concentrations are listed in Tables S2 and S3).

\section{ILI $\beta$ secretion is increased due to a-PVA-SPION treatment, with human monocytes and granulocytes being the primary sources of induced ILI $\beta$}

To identify the cell population(s) responsible for the increased IL1 $\beta$ secretion, we separated CD4 positive T cells, CD14 positive monocytes, and CD15 positive granulocytes from whole blood obtained from HD and incubated them for 20 hours at varying a-PVA-SPION concentrations followed by subsequent IL1 $\beta$ measurement. Surprisingly, there was no influence of a-PVA-SPION on IL1 $\beta$ secretion in each of the single cell populations (data not shown), ie, IL1 $\beta$ was not detectable (except within the corresponding controls). This was in contrast to findings with whole blood experiments. So we repeated the whole blood assay and stained for both specific extracellular cell identity markers and for intracellular IL1 $\beta$ that accumulated in the presence of Brefeldin A. We found a significant or numerical a-PVA-SPION-induced increase in the percentage of IL1 $\beta$ positive cells for all cell types (Figure 3). Granulocytes represented the most commonly stained cell type followed, in descending order, by T cells, monocytes, and B cells, the latter representing the smallest cell population in the blood. The results were normalized to the respective cell counts. Thus both CD15 positive granulocytes and CD14 positive monocytes were identified as the major populations of IL1 $\beta$ producing cells (Figure 3 ). A low a-PVA-SPION concentration $(1 \mu \mathrm{g} / \mathrm{mL})$ did not influence IL1 $\beta$ secretion, whereas medium a-PVASPION concentrations led to a strong numerical $(10 \mu \mathrm{g} / \mathrm{mL})$ or significant $(100 \mu \mathrm{g} / \mathrm{mL}$, one-way ANOVA, $P<0.05)$ increase in the number of IL1 $\beta$ positive cells compared to untreated control. A decline in the number of IL1 $\beta$ positive cells was found for the highest a-PVA-SPION concentration $(1,000 \mu \mathrm{g} / \mathrm{mL})$ compared with concentrations of $100 \mu \mathrm{g} / \mathrm{mL}$ or $10 \mu \mathrm{g} / \mathrm{mL}$ (Figure 3 ).

\section{a-PVA-SPION do not affect the viability of human monocytes but induce increased survival of MDMs in a dose dependent manner}

The main task of monocytes and macrophages is the clearance of pathogens and toxins from the human body. Thus, we analyzed the effects of a-PVA-SPION on the survival of i) isolated monocytes and ii) MDMs (Figure 4). In general, monocytes as well as MDMs exhibit a decrease in numbers over 20 hours. Thus, we have normalized the results to the unstimulated control (considered to be $100 \%$ ). When adding a-PVA-SPION to human CD14 positive monocytes at varying concentrations for 20 hours $(n=8)$, the viability was not affected by nanoparticles compared to the unstimulated control. However, we found a significant decrease in the percentage of viable human monocytes when stimulated with a positive control, namely LPS (38.9\% Annexin V/7AAD negative cells) (Figure 4A). Interestingly, MDMs $(n=10)$ showed a significant increase in the percentage of viable cells at medium and high a-PVA-SPION concentrations compared to the unstimulated control (311.5\% Annexin V/7AAD negative cells for a-PVA-SPION at $100 \mu \mathrm{g} / \mathrm{mL}$ and $450.7 \%$ Annexin V/7AAD negative cells for a-PVA-SPION at $1,000 \mu \mathrm{g} / \mathrm{mL}$ ) (Figure $4 \mathrm{~B})$.

\section{a-PVA-SPION affect the survival of MDMs primarily when added very early during the differentiation process}

Next we analyzed the influence of nanoparticles on the naturally occurring differentiation process by adding

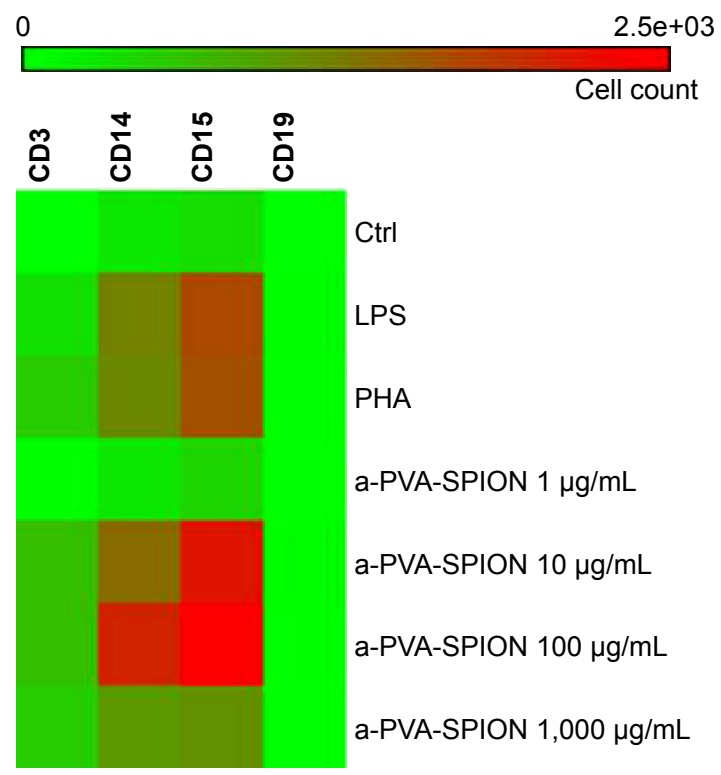

Figure 3 Impact of a-PVA-SPION on the number and distribution of ILI $\beta$ positive cells.

Notes: Whole blood samples obtained from healthy donors $(n=6)$ were incubated for 20 hours at varying a-PVA-SPION concentrations. Cellular transport was blocked by adding Brefeldin A and cells were stained for extracellular markers as well as for intracellular ILI $\beta$. Normalization according to cell count was performed and data were visualized with the help of a heat map. Data are given as number of ILI $\beta$ positive cells.

Abbreviations: Ctrl, control; LPS, lipopolysaccharide; PHA, Phaseolus vulgaris; a-PVA-SPION, amino-polyvinyl alcohol coated superparamagnetic iron oxide nanoparticles. 
A

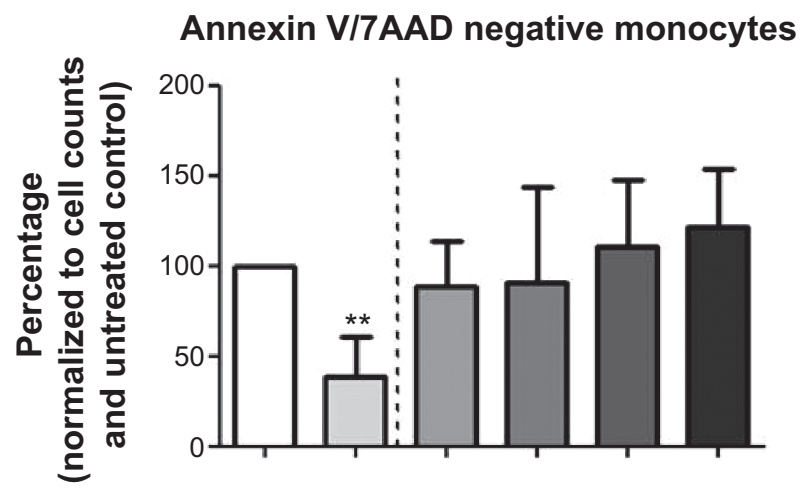

B

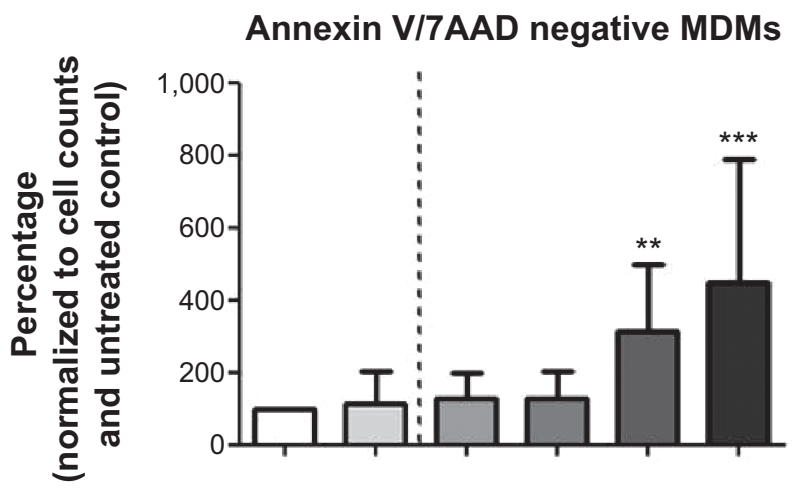

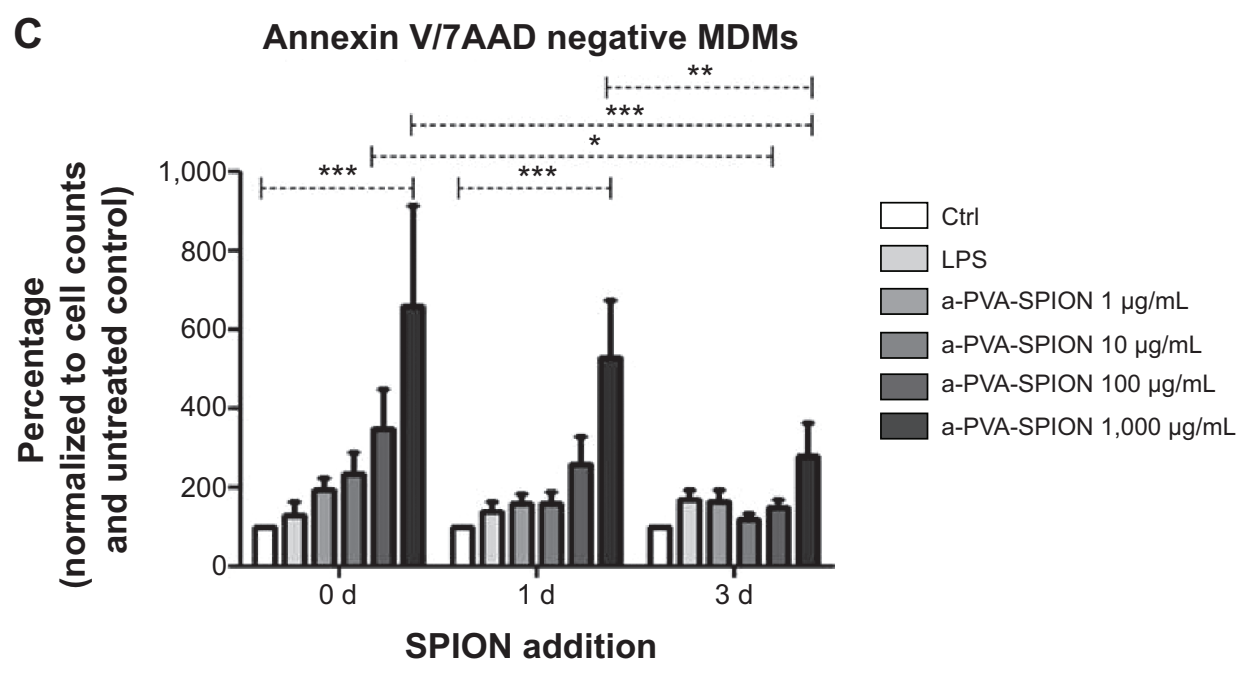

Figure 4 Influence of a-PVA-SPION on the viability of isolated monocytes and monocyte-derived macrophages (MDMs).

Notes: Human monocytes $(\mathbf{A}) n=8$ or MDMs $(\mathbf{B}) n=10$ were incubated for 20 hours with or without SPION at varying concentrations and the percentage of Annexin V/7AAD negative cells was determined. In another experiment the SPION were added during the differentiation process from monocytes to MDMs at the beginning ( $0 \mathrm{~d})$, after 24 hours ( $1 \mathrm{~d}$ ) or after 72 hours ( $3 \mathrm{~d}$ ) and the percentage of Annexin V/7AAD negative cells was determined after a total of 6 days $(\mathbf{C}) \mathrm{n}=7$. Results are normalized to cell counts and untreated control. Data are given as mean \pm standard deviation; two-way ANOVA: $* * * P<0.001 ; * * P<0.01 ; * P<0.05$.

Abbreviations: d, day(s); ANOVA, analysis of variance; Ctrl, control; LPS, lipopolysaccharide; 7AAD, 7-amino-actinomycin D; a-PVA-SPION, amino-polyvinyl alcohol coated superparamagnetic iron oxide nanoparticles.

a-PVA-SPION at different time points during this process. In summary, we found that the survival of MDMs $(n=7)$ was significantly increased in a dose dependent manner, especially when a-PVA-SPION were added very early in the differentiation process (Figure $4 \mathrm{C}$ [0 days]). The later the nanoparticles were added, the weaker the observed increase in cell survival (Figure 4C).

\section{a-PVA-SPION at $1,000 \mu \mathrm{g} / \mathrm{mL}$ are internalized by human monocytes and MDMs}

Monocytes and macrophages are professional phagocytes. Thus, we expected that the a-PVA-SPION are internalized within these cells. However, we aimed to investigate the exact intracellular location of the SPION within the cells, and the extent of their accumulation. To this end, we performed TEM analyses of both untreated (Figure 5A, C) and
a-PVA-SPION $(1,000 \mu \mathrm{g} / \mathrm{mL})$ treated monocytes and MDMs (Figure 5B, D). We found a-PVA-SPION to be present in phagosomes within both monocytes (Figure 5B) and MDMs (Figure 5D). Interestingly, we observed phagosomes that were only partly filled, whereas others were tightly filled with a-PVA-SPION.

\section{Discussion}

There is considerable interest in the use of nanoparticulate materials in the fields of pharmaceuticals and health care industries, as well as in clinical medicine, either for soft materials like liposomes (mostly used for drug delivery) or inorganic hard materials (developed mainly for in vitro or in vivo diagnostics) like SPION. RA is a chronic, systemic, inflammatory autoimmune disease that in large part is diagnosed only after irreversible joint damage is observed using existing imaging modalities. One promising opportunity to 

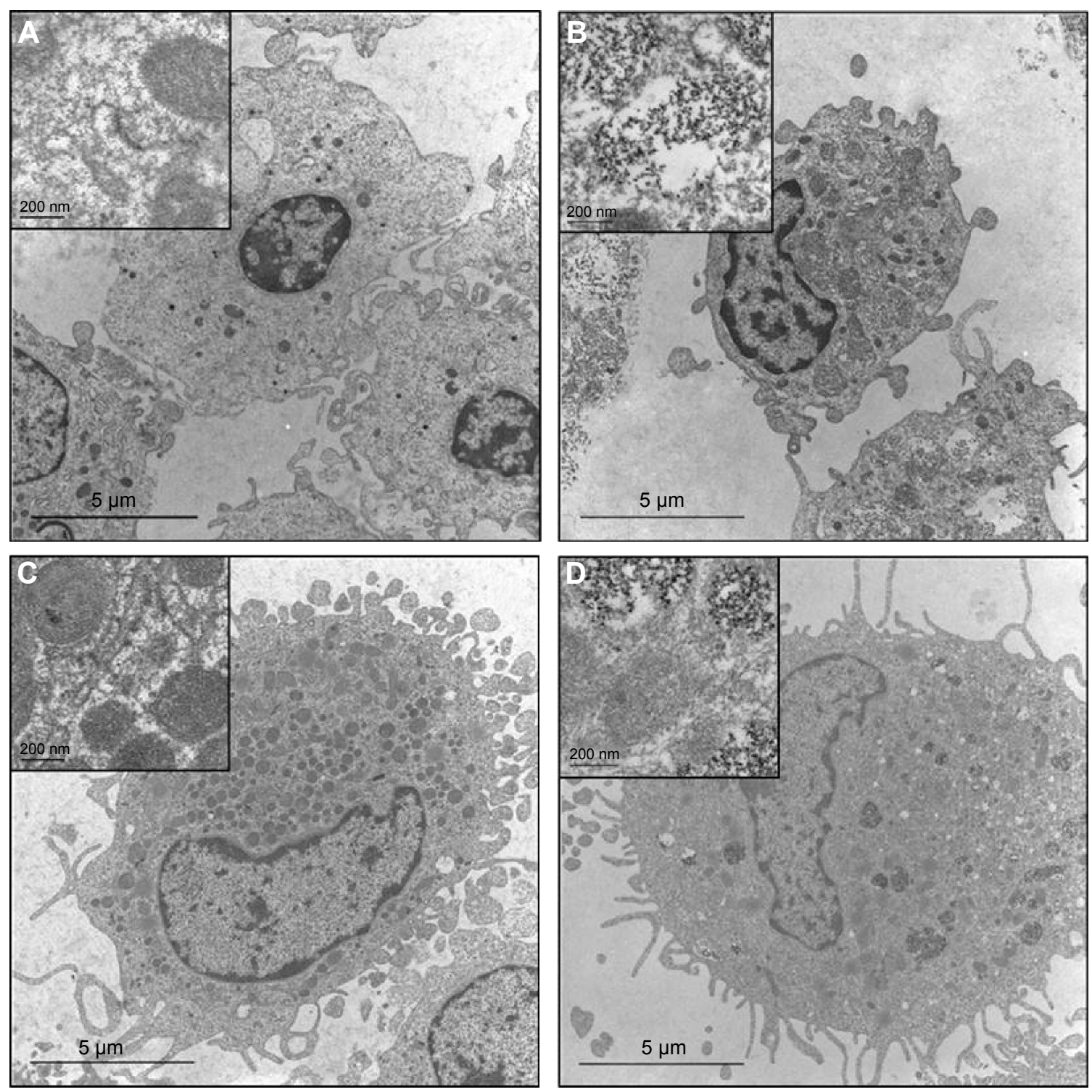

Figure 5 Transmission electron microscopy (TEM) of human monocytes and monocyte-derived macrophages (MDMs) incubated with a-PVA-SPION.

Notes: Human monocytes were incubated for 24 hours without (A) or with (B) a-PVA-SPION (I,000 $\mu \mathrm{g} / \mathrm{mL}$ ). (C, D) Human MDMs were incubated for 24 hours without (C) or with (D) a-PVA-SPION (I,000 $\mu \mathrm{g} / \mathrm{mL})$. Both cell types showed uptake of SPION in phagosomes; some are scattered but others were tightly filled with nanoparticles (scale indicated on the figure).

Abbreviation: a-PVA-SPION, amino-polyvinyl alcohol coated superparamagnetic iron oxide nanoparticles.

achieve an early diagnosis of RA and other inflammatory and degenerative joint diseases, before significant joint destruction occurs, is represented by the use of SPION as MRI contrast agents. SPION are internalized in cells of the mononuclear phagocyte system, in tumor cells as well as in MSCs, which makes these particles of interest for use in MRI. ${ }^{51,62,63}$ The main advantage is that SPION are taken up by immune cells like monocytes, which differentiate to macrophages while migrating into the inflamed tissue. Thus, tissue inflammation can be visualized by MRI in very early disease which enables early therapeutic intervention prior to onset of significant joint damage. This approach is very much in agreement with current treat-to-target guidelines that recommend early and rigorous treatment to achieve low disease activity or remission targets as rapidly as possible.

However, prior to routine usage of novel engineered SPION formulations in medical applications, it is essential to determine any potential toxic effects of these particles. ${ }^{64,65}$ Therefore, in this study we investigated in vitro the interaction between a-PVA-SPION and human immune cells. We aimed to clarify possible toxic effects of a-PVA-SPION on human immune cells using a whole blood system to retain the interaction between the different blood cells and/or soluble 
factors, thereby mimicking as far as possible the in vivo situation. Moreover, the influence of a-PVA-SPION was further analyzed in greater detail using isolated pure cell populations of monocytes or MDMs.

The following major findings emerged from this study: i) a-PVA-SPION had no effect on the survival of human immune cells in the whole blood analysis but ii) the cytokine secretion was dose-dependently increased in this short term study. iii) Using the example of IL1 $\beta$, we were able to show that monocytes and granulocytes were the primary source for this cytokine. Furthermore, when analyzing monocytes and MDMs as pure cell populations in more detail, we found that iv) a-PVA-SPION improved the survival of MDMs in a dose dependent manner and that $v$ ) an early addition of a-PVA-SPION during the differentiation process led to the strongest impact on macrophage survival. Additionally, we were able to show that vi) a-PVA-SPION were internalized in human monocytes and MDMs. The main conclusion of these findings is that there is indeed a potentially clinically relevant interaction of a-PVA-SPION with human immune cells.

Immune cells represent the primary defense system against pathogens. Cells bearing phagocytic functions (especially professional phagocytes such as monocytes, macrophages, and polymorphonuclear granulocytes or neutrophils) are equipped with receptors that recognize foreign invaders. ${ }^{66}$ One reaction after the detection of external substances within the human body is the secretion of cytokines and chemokines to alert and attract further immune cells that migrate into the affected area. In this study we demonstrated that the secretion of different cytokines is increased due to a-PVA-SPION treatment in a whole blood system. This is in contrast to the results on isolated human MDMs, which found no difference in the production of several cytokines (IL12, IL6, TNF- $\alpha$, and IL1 $\beta$ ) in MDMs that were stimulated with dextran coated ultrasmall superparamagnetic iron oxide particle (Ferumoxtran-10) compared to untreated controls. ${ }^{67}$ Whether or not the effect of the SPION in our study is persistent or short-lived is not known. Further studies are required to examine this.

Another interesting study revealed that LPS pre-treated monocyte-derived dendritic cells co-cultured with CD4 $\mathrm{T}$ cells show a SPION dependent decrease in IL1 $\beta$ secretion. ${ }^{54}$ When analyzing the IL $1 \beta$ secretion in more detail in our study, we first incubated isolated T cells, monocytes and granulocytes with a-PVA-SPION in order to quantify the supernatants with regard to this cytokine. Interestingly, with the exception of the respective control, there was no measurable amount of IL1 $\beta$ in the supernatants after a-PVA-SPION stimulation (data not shown). But for both the whole blood cytokine secretion assay and the whole blood intracellular IL1 $\beta$ staining the results on cytokine production were precise and reproducible. Thus, we assume that analysis of isolated single cell populations is not representative of the complex human in vivo situation where interactions between immune cells and other cells and soluble factors exist. Nevertheless, the question arises whether this effect on cytokine secretion (especially IL1 $\beta$ ) is of importance for the assessment of SPION toxicology. In freshly drawn blood, IL1 $\beta$ serum levels of $5.5 \mathrm{pg} / \mathrm{mL}$ for RA patients and $2.6 \mathrm{pg} / \mathrm{mL}$ for HD have been reported. ${ }^{6}$ After incubation, we found median values of $96.3 \mathrm{pg} / \mathrm{mL}$ and $54.9 \mathrm{pg} / \mathrm{mL}$ IL1 $\beta$ for RA patients and HD in the untreated control, respectively. The difference with regard to freshly drawn blood may result from the incubation time of 20 hours, when apoptosis and consequently cell lysis may take place (see results of the whole blood survival assay), which mediate the release of soluble factors. These serum values were increased up to $2,000 \mathrm{pg} / \mathrm{mL}$ in our positive control, which is represented by LPS at high dosages. Similar values could be observed for a-PVA-SPION used at concentrations $>10 \mu \mathrm{g} / \mathrm{mL}$. These results show that the batch of a-PVA-SPION used does indeed trigger a dose-dependent effect that is comparable to an inflammatory process. Thus, for some in vitro studies these SPION are usable but they are not feasible for in vivo imaging techniques that exceed local a-PVA-SPION concentrations of $10 \mu \mathrm{g} / \mathrm{mL}$. Further modulation of the formulation may possibly reduce this cytokine secretion thereby overcoming this problem, since we were able to show that there is no toxic effect with regard to survival and since we do not expect our immune cells to be totally inert when in contact with a-PVA-SPION. Furthermore, when thinking of the in vivo situation, one has to keep in mind that the properties of the peripheral blood and the tissues, especially in the case of inflammation, vary strongly. One example is oxygen availability, which is sufficient in the blood stream but deficient in inflamed tissues. Thus, immune cells have to adapt to these changes when infiltrating the inflamed area. ${ }^{69}$ These environmental changes could result in a completely different behavior of immune cells, compared to our findings for peripheral blood cells. Another important consideration is the concentration of SPION that is attained in vivo when used as a contrast agent in clinical studies. Both questions remain to be analyzed in future studies.

A key immune cell, whose principal task is the recognition, uptake and lysis of foreign invaders, is the professional phagocyte. ${ }^{66}$ Such cells do not distinguish between microbes, 
foreign cell debris, apoptotic cells or nanoparticles. Our results indicate that a-PVA-SPION are endocytosed by monocytes and MDMs, which is in accordance with other studies. ${ }^{67,70}$ When nanoparticles enter the cell, they can sometimes directly interact with the cytosol while during phagocytosis these particles are retained within vesicles. ${ }^{71-73}$ Hence, the intracellular location of nanoparticles depends on the uptake mechanism, which in turn depends on the type and the charge of the nanoparticle. For example Schweiger et al reported that negatively charged SPION were found firstly in endosomes and later in lysosomes, whereas positively charged particles were found exclusively in lysosomes. ${ }^{71}$ Since we used a-PVA-SPION in RPMI media without FCS, the Zeta potential of the particles is slightly positive, which leads to the assumption that the a-PVA-SPION are located in lysosomes. Rich in digestive enzymes, the lysosomes are responsible for the dissolution of pathogens. In general, monocytes are patrolling cells within the bloodstream that recognize pathogens or respond to inflammatory stimuli. ${ }^{69}$ Once activated, a differentiation process is initiated that leads to the development of macrophages. These cells primarily ingest the pathogens for rapid killing and elimination and further regulate inflammatory reactions by producing proinflammatory or anti-inflammatory cytokines. ${ }^{74-76}$ Incubation with nanoparticles clearly triggers an activation process, whereas monocyte survival is not influenced. But when considering macrophages, it became obvious that the number of differentiated, viable cells was increased by a-PVASPION contact. Our results indicate that more monocytes are triggered to become macrophages, thereby assimilating and removing the foreign invader and enhancing immunity. This may facilitate further uses of nanoparticles. Monocytes and macrophages have recently been identified as interesting targets for both diagnosis and treatment of inflammatory diseases such as RA. ${ }^{77}$ A directed uptake of specific nanoparticle formulations by monocytes and macrophages, which migrate into the inflamed tissue, is desirable on the one hand for imaging as shown by the NanoDiaRA project results, thereby enabling early diagnosis of RA. ${ }^{78}$ On the other hand, conjugation of nanoparticles that invade inflamed tissue with disease modifying drugs may optimize treatment strategies in the future.

\section{Conclusion}

Our study clearly demonstrates that there are mixed effects of a-PVA-SPION on human immune cells. Thus they do not appear to have any observable toxic effects on the survival of the immune cells investigated. However, they promote differentiation to and increased survival of MDMs, which are important human professional phagocytes and thus favor the expression of immunity. The analysis of cytokine secretion revealed that a-PVA-SPION trigger dose-dependent release of some cytokines that is comparable to an acute inflammatory process of unknown duration. Moreover, the concentration of a-PVA-SPION that would be used in imaging remains to be determined. It may be similar or lower than the dose range used here. Therefore, we have obtained a nuanced conclusion, where the expected cytokine secretion as an immune response from professional phagocytes to a foreign substance was present but to a lesser extent than anticipated. SPION particles of this kind, which have already been generated with different surface modifications, will require examination in studies of this kind to determine the nature of the human immune responses they might generate. That these in vitro studies are of importance is apparent, especially once the local in vivo concentrations of SPION have been determined.

\section{Outlook}

In future, the use of nanomaterials is likely to increase since these substances open up previously unforeseen opportunities due to their special properties. In particular, nanoparticles represent a promising tool in the field of human medicine, for example as MRI contrast agents. It has been recently demonstrated that these particles are taken up by human MSCs and therefore could probably be used for cell-based therapies. ${ }^{51}$ Interestingly, we were able to demonstrate that these particles are also taken up by human macrophages, which are known to migrate into inflamed tissue. This might facilitate very early visualization of tissue inflammation by MRI, thereby enabling an early therapeutic intervention prior to onset of significant joint damage. Some studies using these nanoparticles proved their efficiency to target and monitor in vivo the inflammation of knee joints treated with dexamethasone using a-PVA-SPION labeled macrophages. ${ }^{79}$

However, as with any novel technology, a number of critical issues must be resolved before using these a-PVASPION in human medicine. Specifically, these particles have first to be modified to a certain degree to be usable in vivo in the human system. One possibility would be to use the PVA coating properties to cross-link the polymer on the surface of the SPION or to functionalize them with reactive groups to target specific diseases. ${ }^{80}$ Of course, these new modifications will need further in vitro studies. However, once a suitable formulation has been established, it may facilitate prevention of joint damage arising from RA. 


\section{Acknowledgments}

We would like to thank Manuela Jakstadt for outstanding technical assistance, Barbara Szostak and Heide Boeth for sample collection and archiving, Sebastian Bachmann and Petra Schrade for their guidance in TEM analysis (all Charité Berlin) and Marie-Gabrielle Beuzelin (EPFL Switzerland) and Usawadee Sakulkhu for their support.

\section{Disclosure}

This work has been supported by the NanoDiaRA project, grant agreement number 228929, funded by the European Seventh Framework Programme FP7-NMP-2008-L.

The authors have no other relevant affiliations or financial involvement with any organization or entity with a financial interest in or financial conflict with the subject matter or materials discussed in the manuscript apart from those disclosed. The authors report no other conflicts of interest.

\section{References}

1. Feldmann M, Brennan FM, Maini RN. Rheumatoid arthritis. Cell. 1996;85(3):307-310.

2. Feldmann M, Brennan FM, Foxwell BM, Maini RN. The role of TNF alpha and IL-1 in rheumatoid arthritis. Cur Dir Autoimmun 2001;3:188-199.

3. Firestein GS. Invasive fibroblast-like synoviocytes in rheumatoid arthritis. Passive responders or transformed aggressors? Arthritis Rheum. 1996;39(11):1781-1790.

4. McInnes IB, Schett G. Cytokines in the pathogenesis of rheumatoid arthritis. Nature reviews. Nat Rev Immunol. 2007;7(6):429-442.

5. Burger D, Dayer JM, Palmer G, Gabay C. Is IL-1 a good therapeutic target in the treatment of arthritis? Best Pract Res Clin Rheumatol. 2006;20(5):879-896.

6. Schett G. Erosive arthritis. Arthritis Res Ther. 2007;9 Suppl 1:S2.

7. Michaud K, Wolfe F. Comorbidities in rheumatoid arthritis. Best Pract Res Clin Rheumatol. 2007;21(5):885-906.

8. Zink A, Manger B, Kaufmann J, et al. Evaluation of the RABBIT Risk Score for serious infections. Ann Rheum Dis. 2014;73(9):1673-1676.

9. Strangfeld A, Eveslage M, Schneider M, et al. Treatment benefit or survival of the fittest: what drives the time-dependent decrease in serious infection rates under TNF inhibition and what does this imply for the individual patient? Ann Rheum Dis. 2011;70(11):1914-1920.

10. Gabriel SE. The epidemiology of rheumatoid arthritis. Rheum Dis Clin North Am. 2001;27(2):269-281.

11. Barton A, Worthington J. Genetic susceptibility to rheumatoid arthritis: an emerging picture. Arthritis Rheum. 2009;61(10):1441-1446.

12. Carlens C, Hergens MP, Grunewald J, et al. Smoking, use of moist snuff, and risk of chronic inflammatory diseases. Am J Respir Crit Care Med. 2010;181(11):1217-1222.

13. MacGregor AJ, Snieder H, Rigby AS, et al. Characterizing the quantitative genetic contribution to rheumatoid arthritis using data from twins. Arthritis Rheum. 2000;43(1):30-37.

14. Silman AJ, Newman J, MacGregor AJ. Cigarette smoking increases the risk of rheumatoid arthritis. Results from a nationwide study of disease-discordant twins. Arthritis Rheum. 1996;39(5):732-735.

15. Lindqvist E, Eberhardt K, Bendtzen K, Heinegard D, Saxne T. Prognostic laboratory markers of joint damage in rheumatoid arthritis. Ann Rheum Dis. 2005;64(2):196-201.

16. Bird P, Conaghan P, Ejbjerg B, et al. The development of the EULAROMERACT rheumatoid arthritis MRI reference image atlas. Ann Rheum Dis. 2005;64 Suppl 1:i8-i10.
17. Backhaus M, Kamradt T, Sandrock D, et al. Arthritis of the finger joints: a comprehensive approach comparing conventional radiography, scintigraphy, ultrasound, and contrast-enhanced magnetic resonance imaging. Arthritis Rheum. 1999;42(6):1232-1245.

18. Reiche BE, Ohrndorf S, Feist E, Messerschmidt J, Burmester GR, Backhaus M. Power doppler ultrasound is useful for prediction of re-therapy with rituximab in rheumatoid arthritis. Arthritis Care Res (Hoboken). 2014;66(2):204-216.

19. Brennan FM, Chantry D, Jackson A, Maini R, Feldmann M. Inhibitory effect of TNF alpha antibodies on synovial cell interleukin-1 production in rheumatoid arthritis. Lancet. 1989;2(8657):244-247.

20. Elliott MJ, Maini RN, Feldmann M, et al. Treatment of rheumatoid arthritis with chimeric monoclonal antibodies to tumor necrosis factor alpha. Arthritis Rheum. 1993;36(12):1681-1690.

21. Lipsky PE, van der Heijde DM, St Clair EW, et al. Infliximab and methotrexate in the treatment of rheumatoid arthritis. Anti-Tumor Necrosis Factor Trial in Rheumatoid Arthritis with Concomitant Therapy Study Group. N Engl J Med. 2000;343(22):1594-1602.

22. Strangfeld A, Hierse F, Rau R, et al. Risk of incident or recurrent malignancies among patients with rheumatoid arthritis exposed to biologic therapy in the German biologics register RABBIT. Arthritis Res Ther. 2010;12(1):R5.

23. Dreyer L, Mellemkjaer L, Andersen AR, et al. Incidences of overall and site specific cancers in TNFalpha inhibitor treated patients with rheumatoid arthritis and other arthritides - a follow-up study from the DANBIO Registry. Ann Rheum Dis. 2013;72(1):79-82.

24. Listing J, Kekow J, Manger B, et al. Mortality in rheumatoid arthritis: the impact of disease activity, treatment with glucocorticoids, TNFalpha inhibitors and rituximab. Ann Rheum Dis. 2015;74(2): 415-421.

25. Raza K, Saber TP, Kvien TK, Tak PP, Gerlag DM. Timing the therapeutic window of opportunity in early rheumatoid arthritis: proposal for definitions of disease duration in clinical trials. Ann Rheum Dis. 2012;71(12):1921-1923.

26. Kyburz D, Finckh A. The importance of early treatment for the prognosis of rheumatoid arthritis. Swiss Med Wkly. 2013;143:w13865.

27. Allaire S, Wolfe F, Niu J, LaValley MP, Zhang B, Reisine S. Current risk factors for work disability associated with rheumatoid arthritis: recent data from a US national cohort. Arthritis Rheum. 2009;61(3):321-328.

28. Shubayev VI, Pisanic TR 2nd, Jin S. Magnetic nanoparticles for theragnostics. Adv Drug Deliv Rev. 2009;61(6):467-477.

29. Maier-Hauff K, Ulrich F, Nestler D, et al. Efficacy and safety of intratumoral thermotherapy using magnetic iron-oxide nanoparticles combined with external beam radiotherapy on patients with recurrent glioblastoma multiforme. J Neurooncol. 2011;103(2):317-324.

30. Wang YX, Hussain SM, Krestin GP. Superparamagnetic iron oxide contrast agents: physicochemical characteristics and applications in MR imaging. Eur Radiol. 2001;11(11):2319-2331.

31. Lodhia J, Mandarano G, Ferris N, Eu P, Cowell S. Development and use of iron oxide nanoparticles (Part 1): Synthesis of iron oxide nanoparticles for MRI. Biomed Imaging Interv J. 2010;6(2):e12.

32. Mandarano G LJ, Eu P, Ferris NJ, Davidson R, Cowell SF. Development and use of iron oxide nanoparticles (Part 2): The application of iron oxide contrast agents in MRI. Biomed Imaging Interv J. 2010;6(2): e13

33. You DG, Saravanakumar G, Son S, et al. Dextran sulfate-coated superparamagnetic iron oxide nanoparticles as a contrast agent for atherosclerosis imaging. Carbohydr Polym. 2014;101:1225-1233.

34. Saraswathy A, Nazeer SS, Nimi N, Arumugam S, Shenoy SJ, Jayasree RS. Synthesis and characterization of dextran stabilized superparamagnetic iron oxide nanoparticles for in vivo MR imaging of liver fibrosis. Carbohydr Polym. 2014;101:760-768.

35. Markides H, Kehoe O, Morris RH, El Haj AJ. Whole body tracking of superparamagnetic iron oxide nanoparticle-labelled cells - a rheumatoid arthritis mouse model. Stem Cell Res Ther. 2013; $4(5): 126$. 
36. Runge VM. Safety of approved MR contrast media for intravenous injection. J Magn Reson Imaging. 2000;12(2):205-213.

37. Bulte JW, Kraitchman DL. Iron oxide MR contrast agents for molecular and cellular imaging. NMR Biomed. 2004;17(7):484-499.

38. Eckstein F, Cicuttini F, Raynauld JP, Waterton JC, Peterfy C. Magnetic resonance imaging (MRI) of articular cartilage in knee osteoarthritis (OA): morphological assessment. Osteoarthritis Cartilage. 2006; 14 Suppl A:A46-A75.

39. Eckstein F, Burstein D, Link TM. Quantitative MRI of cartilage and bone: degenerative changes in osteoarthritis. NMR Biomed. 2006;19(7):822-854.

40. MacKenzie JD KD. Imaging of Rheumatoid Arthritis. In: Weissman BNW, editor. Imaging of Arthritis and Metabolic Bone Disease. Elsevier Health Sciences; 2009:340-364.

41. Kosta PE, Voulgari PV, Zikou AK, Drosos AA, Argyropoulou MI. The usefulness of magnetic resonance imaging of the hand and wrist in very early rheumatoid arthritis. Arthritis Res Ther. 2011;13(3):R84.

42. Filippo Del Grande AJF, Abraham Padua RT, John A Carrino. The Importance of MRI of the Wrist in Patients with Rheumatoid Arthritis. Siemens Healthcare. 2011. Available from: http://usa.healthcare. siemens.com/siemens_hwem-hwem_ssxa_websites-context-root/ wcm/idc/siemens_hwem-hwem_ssxa_websites-context-root/wcm/idc/ groups/public/@global/@imaging/@mri/documents/download/mdaw/ mtu3/ edisp/the_importance_of_mri_of_wrist_in_patients_with_rheumatoid_arthritis_neu-00019770.pdf. Accessed January 12, 2015.

43. Sanjeeva P Kalva, Blake MA, Dushyant V Sahani. MR contrast agents. Applied Radiology. 2006:18-27.

44. Simon GH, von Vopelius-Feldt J, Wendland MF, et al. MRI of arthritis: comparison of ultrasmall superparamagnetic iron oxide vs Gd-DTPA. J Magn Reson Imaging. 2006;23(5):720-727.

45. Wang J, Chen Y, Chen B, et al. Pharmacokinetic parameters and tissue distribution of magnetic $\mathrm{Fe}(3) \mathrm{O}(4)$ nanoparticles in mice. Int $J$ Nanomedicine. 2010;5:861-866.

46. Yang CY, Tai MF, Lin CP, et al. Mechanism of cellular uptake and impact of ferucarbotran on macrophage physiology. PloS One. 2011;6(9):e25524.

47. Raynal I, Prigent P, Peyramaure S, Najid A, Rebuzzi C, Corot C. Macrophage endocytosis of superparamagnetic iron oxide nanoparticles: mechanisms and comparison of ferumoxides and ferumoxtran-10. Invest Radiol. 2004;39(1):56-63.

48. Chao Y, Makale M, Karmali PP, et al. Recognition of DextranSuperparamagnetic Iron Oxide Nanoparticle Conjugates (Feridex) via Macrophage Scavenger Receptor Charged Domains. Bioconjug Chem. 2012;23(5):1003-1009.

49. Lunov O, Zablotskii V, Syrovets T, et al. Modeling receptor-mediated endocytosis of polymer-functionalized iron oxide nanoparticles by human macrophages. Biomaterials. 2011;32(2):547-555.

50. Schöpf B. Chemische und physikalische Nachweismethoden Superparamagnetischer Nanopartikel zur Beurteilung deren Wirkung auf Zellen des Bewegungsapparates In vitro Studie an Osteoblasten, Chondrozyten und Synovialzellen von Schafen [PhD thesis]: VetsuisseFakultät Universität Zürich, Pferdeklinik, Musculoskeletal Research Unit, Universität Zürich; 2004.

51. Schulze F, Dienelt A, Geissler S, et al. Amino-polyvinyl Alcohol Coated Superparamagnetic Iron Oxide Nanoparticles are Suitable for Monitoring of Human Mesenchymal Stromal Cells In Vivo. Small. 2014;10(21):4340-4351.

52. Petri-Fink A, Steitz B, Finka A, Salaklang J, Hofmann H. Effect of cell media on polymer coated superparamagnetic iron oxide nanoparticles (SPIONs): colloidal stability, cytotoxicity, and cellular uptake studies. Eur J Pharm Biopharm. 2008;68(1):129-137.

53. Mahmoudi M, Hofmann H, Rothen-Rutishauser B, Petri-Fink A. Assessing the in vitro and in vivo toxicity of superparamagnetic iron oxide nanoparticles. Chem Rev. 2012;112(4):2323-2338.

54. Blank F, Gerber P, Rothen-Rutishauser B, et al. Biomedical nanoparticles modulate specific $\mathrm{CD} 4+\mathrm{T}$ cell stimulation by inhibition of antigen processing in dendritic cells. Nanotoxicology. 2011;5(4):606-621.
55. Soenen SJ, Himmelreich U, Nuytten N, De Cuyper M. Cytotoxic effects of iron oxide nanoparticles and implications for safety in cell labelling. Biomaterials. 2011;32(1):195-205.

56. Hoskins C, Cuschieri A, Wang L. The cytotoxicity of polycationic iron oxide nanoparticles: common endpoint assays and alternative approaches for improved understanding of cellular response mechanism. J Nanobiotechnology. 2012;10:15.

57. Cornwell RM, Schwertmann U. The iron oxides: structure, properties, reactions, occurrence and uses. 2nd ed: Wiley-VCH, Weinheim; 2006.

58. Chastellain M, Petri A, Gupta A, Rao KV, Hofmann H. Superparamagnetic Silica-Iron Oxide Nanocomposites for Application in Hyperthermia. Advanced Engineering Materials. 2004;6(4):235-241.

59. Arnett FC, Edworthy SM, Bloch DA, et al. The American Rheumatism Association 1987 revised criteria for the classification of rheumatoid arthritis. Arthritis Rheum. 1988;31(3):315-324.

60. Bachmann S, Schlichting U, Geist B, et al. Kidney-specific inactivation of the megalin gene impairs trafficking of renal inorganic sodium phosphate cotransporter (NaPi-IIa). J Am Soc Nephrol. 2004;15(4):892-900.

61. Dormann JL, Fiorani D, Tronc E. Magnetic Relaxation in Fine-Particle Systems. In: Prigogine I, Rice SA, eitors. Advances in Chemical Physics. John Wiley \& Sons, Inc.; 1997:283-494.

62. Rodenstein DO, Stanescu DC, Delguste P, Liistro G, Aubert-Tulkens G. Adaptation to intermittent positive pressure ventilation applied through the nose during day and night. Eur Respir J. 1989;2(5):473-478.

63. Pouliquen D, Le Jeune JJ, Perdrisot R, Ermias A, Jallet P. Iron oxide nanoparticles for use as an MRI contrast agent: pharmacokinetics and metabolism. Magn Reson Imaging. 1991;9(3):275-283.

64. Shvedova AA, Kagan VE, Fadeel B. Close encounters of the small kind: adverse effects of man-made materials interfacing with the nano-cosmos of biological systems. Annu Rev Pharmacol Toxicol. 2010;50:63-88.

65. Kahru A, Ivask A. Mapping the dawn of nanoecotoxicological research. Acc Chem Res. 2013;46(3):823-833.

66. Aderem A, Underhill DM. Mechanisms of phagocytosis in macrophages. Annu Rev Immunol. 1999;17:593-623.

67. Muller K, Skepper JN, Posfai M, et al. Effect of ultrasmall superparamagnetic iron oxide nanoparticles (Ferumoxtran-10) on human monocytemacrophages in vitro. Biomaterials. 2007;28(9):1629-1642.

68. Kokkonen H, Soderstrom I, Rocklov J, Hallmans G, Lejon K, Rantapaa Dahlqvist S. Up-regulation of cytokines and chemokines predates the onset of rheumatoid arthritis. Arthritis Rheum. 2010;62(2):383-391.

69. Strehl C, Fangradt M, Fearon U, Gaber T, Buttgereit F, Veale DJ. Hypoxia: how does the monocyte-macrophage system respond to changes in oxygen availability? J Leukoc Biol. 2014;95(2):233-241.

70. Monteiro-Riviere NA, Inman AO, Zhang LW. Limitations and relative utility of screening assays to assess engineered nanoparticle toxicity in a human cell line. Toxicol Appl Pharmacol. 2009;234(2): 222-235.

71. Schweiger C, Hartmann R, Zhang F, Parak WJ, Kissel TH, Rivera Gil P. Quantification of the internalization patterns of superparamagnetic iron oxide nanoparticles with opposite charge. J Nanobiotechnology. 2012;10:28.

72. Joris F, Manshian BB, Peynshaert K, De Smedt SC, Braeckmans K, Soenen SJ. Assessing nanoparticle toxicity in cell-based assays: influence of cell culture parameters and optimized models for bridging the in vitro-in vivo gap. Chem Soc Rev. 2013;42(21):8339-8359.

73. Wang T, Bai J, Jiang X, Nienhaus GU. Cellular uptake of nanoparticles by membrane penetration: a study combining confocal microscopy with FTIR spectroelectrochemistry. ACS Nano. 2012;6(2):1251-1259.

74. Jonuleit H, Schmitt E, Schuler G, Knop J, Enk AH. Induction of interleukin 10-producing, nonproliferating $\mathrm{CD} 4(+) \mathrm{T}$ cells with regulatory properties by repetitive stimulation with allogeneic immature human dendritic cells. J Exp Med. 2000;192(9):1213-1222.

75. Katoh N, Soga F, Nara T, Masuda K, Kishimoto S. Histamine induces the generation of monocyte-derived dendritic cells that express CD14 but not CD1a. J Invest Dermatol. 2005;125(4):753-760. 
76. Novak N, Bieber T, Katoh N. Engagement of Fc epsilon RI on human monocytes induces the production of IL-10 and prevents their differentiation in dendritic cells. J Immunol. 2001;167(2):797-804.

77. Lameijer MA, Tang J, Nahrendorf M, Beelen RH, Mulder WJ. Monocytes and macrophages as nanomedicinal targets for improved diagnosis and treatment of disease. Expert Rev Mol Diagn. 2013;13(6):567-580.

78. Development of Novel Nanotechnology Based Diagnostic Systems for Rheumatoid Arthritis and Osteoarthritis (NanoDiaRA) www. nanodiara.eu
79. Gramoun A, Crowe LA, Maurizi L, et al. Monitoring the effects of dexamethasone treatment by MRI using in vivo iron oxide nanoparticlelabeled macrophages. Arthritis Res Ther. 2014;16(3):R131.

80. Maurizi L, Sakulkhu U, Crowe LA, et al. Syntheses of cross-linked polymeric superparamagnetic beads with tunable properties. RSC $A d v$. 2014;4(22):11142-11146. 


\section{Supplementary materials}

Table SI Characteristics of patients with RA at screening visit

\begin{tabular}{lc}
\hline Characteristics & RA patients $(\mathbf{n}=19)$ \\
\hline Female:male & $16: 3$ \\
Age (years)* & $56.42(24 / 75)$ \\
Duration of RA (years)* & $10.3(0.2 / 37.6)$ \\
RF* $^{*}$ & $23 I(1 / 1,600)$ \\
ACPA & $241.7(0 / 1,000)$ \\
DAS28* & $4.81(2.72 / 6.86)$ \\
ESR $(\mathrm{mm} / \mathrm{h})^{*}$ & $22.68(2 / 60)$ \\
CRP $(\mathrm{mg} / \mathrm{dL})^{*}$ & $0.98(0.03 / 6.56)$ \\
Glucocorticoid treatment & $13(68 \%)$ \\
DMARDs & $19(100 \%)$ \\
NSAIDs & $11(58 \%)$ \\
\hline
\end{tabular}

Note: Data are given as *mean (minimum/maximum) or number (\%).

Abbreviations: RF, rheumatoid factor; ACPA, anti-citrullinated peptide antibodies; DAS28, disease activity score of 28 joints; ESR, erythrocyte sedimentation rate; CRP, c-reactive protein; DMARDs, disease modifying antirheumatic drugs; NSAIDs, non-steroidal anti-inflammatory drugs; RA, rheumatoid arthritis.

Table S2 Influence of a-PVA-SPION on the concentration of secreted cytokines in whole blood samples obtained from RA patients

\begin{tabular}{|c|c|c|c|c|c|c|c|c|}
\hline Cytokine & Ctrl & LPS & PHA & $\begin{array}{l}\text { a-PVA-SPION } \\
\text { I } \mu \mathrm{g} / \mathrm{mL}\end{array}$ & $\begin{array}{l}\text { a-PVA-SPION } \\
10 \mu \mathrm{g} / \mathrm{mL}\end{array}$ & $\begin{array}{l}\text { a-PVA-SPION } \\
100 \mu \mathrm{g} / \mathrm{mL}\end{array}$ & $\begin{array}{l}\text { a-PVA-SPION } \\
\mathrm{I}, 000 \mu \mathrm{g} / \mathrm{mL}\end{array}$ & $\begin{array}{l}\text { Norm-serum- } \\
\text { level* }\end{array}$ \\
\hline ILI ra [pg/mL] & 146 & 1,164 & 740 & 106 & 546 & 588 & 277 & 133 \\
\hline $\mathrm{ILI} \beta[\mathrm{pg} / \mathrm{mL}]$ & 13 & 706 & 125 & 15 & 57 & $|, 66|$ & 1,303 & 3 \\
\hline IL2 [pg/mL] & nd & nd & nd & nd & nd & nd & nd & I \\
\hline $\mathrm{IL} 4[\mathrm{pg} / \mathrm{mL}]$ & 8 & 18 & 18 & 7 & 12 & 20 & 15 & 3 \\
\hline IL5 [pg/mL] & nd & nd & nd & nd & nd & nd & nd & 4 \\
\hline IL6 [pg/mL] & 16 & 22,147 & 5,242 & 46 & 474 & $|8,8| 8$ & 20,102 & 5 \\
\hline IL7 [pg/mL] & nd & nd & nd & nd & nd & nd & nd & 21 \\
\hline IL8 [pg/mL] & 81 & 8,025 & 7,460 & 508 & 5,762 & 17,279 & 20,050 & 4 \\
\hline IL9 [pg/mL] & 52 & 129 & 129 & 39 & 68 & 118 & 139 & 12 \\
\hline ILIO [pg/mL] & 3 & 290 & 220 & 3 & 9 & 70 & 125 & 4 \\
\hline ILI2 [pg/mL] & 31 & 67 & 66 & 36 & 37 & 68 & 82 & 16 \\
\hline ILI $3[\mathrm{pg} / \mathrm{mL}]$ & nd & nd & nd & nd & nd & nd & nd & 4 \\
\hline ILI 5 [pg/mL] & nd & nd & nd & nd & nd & nd & nd & I \\
\hline ILI7 [pg/mL] & 17 & 101 & 182 & 17 & 74 & 128 & 120 & 21 \\
\hline Eotaxin $[\mathrm{pg} / \mathrm{mL}]$ & 91 & 115 & 87 & 103 & 86 & 101 & 86 & 31 \\
\hline FGF basic $[\mathrm{pg} / \mathrm{mL}]$ & 17 & 24 & 24 & 13 & 17 & 26 & 20 & 7 \\
\hline G-CSF $[p g / m L]$ & 35 & 189 & 82 & 29 & 75 & 627 & 1,040 & 52 \\
\hline $\mathrm{GM}-\mathrm{CSF}[\mathrm{pg} / \mathrm{mL}]$ & 158 & 118 & 121 & 114 & 99 & 145 & 147 & 6 \\
\hline $\mathrm{IFN}-\gamma[\mathrm{pg} / \mathrm{mL}]$ & 380 & 1,249 & 901 & 357 & 487 & 1,110 & 1,055 & 77 \\
\hline $\mathrm{MCPI}[\mathrm{pg} / \mathrm{mL}]$ & $|3|$ & 1,924 & 7,455 & 553 & 8,911 & 11,732 & 10,834 & 16 \\
\hline MIPIa $[\mathrm{pg} / \mathrm{mL}]$ & 21 & $\mathrm{I}, 708$ & 1,381 & 24 & 115 & I,886 & $\mathrm{I}, 845$ & 7 \\
\hline MIPIb [pg/mL] & 178 & 9,369 & 9,639 & 467 & 2,472 & 11,227 & 7,897 & 35 \\
\hline$|\mathrm{PI}| 0[\mathrm{pg} / \mathrm{mL}]$ & 1,267 & 8,238 & 11,175 & 913 & $\mathrm{I}, 524$ & I,372 & 682 & 592 \\
\hline PDGF $[\mathrm{pg} / \mathrm{mL}]$ & $\mathrm{I}, 445$ & 2,496 & 3,135 & 1,518 & 1,963 & 4,096 & 2,824 & $|, 57|$ \\
\hline RANTES [pg/mL] & 4,732 & 8,659 & 7,048 & 4,892 & 6,878 & 8,491 & 8,788 & $204^{\&}$ \\
\hline $\mathrm{TNF} \alpha[\mathrm{pg} / \mathrm{mL}]$ & 40 & 1,273 & 661 & 30 & 118 & 348 & 113 & 35 \\
\hline VEGF $[\mathrm{pg} / \mathrm{mL}]$ & 48 & 145 & 136 & 70 & 45 & 77 & 203 & II \\
\hline
\end{tabular}

Notes: Supernatants were collected from whole blood survival assays (blood samples obtained from patients with RA) after 20 hours with or without SPION treatment and analyzed by multiplex suspension array. Supernatants from nine RA patients were analyzed, median values are shown for the controls (LPS, PHA) and the different SPION concentrations (I-I,000 $\mu \mathrm{g} / \mathrm{mL})$. *Adapted from Up-regulation of cytokines and chemokines predates the onset of rheumatoid arthritis, Arthritis \& Rheumatism, John Wiley and Sons. Copyright (C) 2010 by the American College of Rheumatology. ' ${ }^{8}$ Copyright @ 2010. Bio-Rad Laboratories, Inc. Adapted from Chapman P, Reyes C, Gupta V. Normal Physiological Levels of Human Cytokines Using Bio-Plex Pro TM Cytokine Assays. Bio-Rad Tech Note. 2010;6029. Available from: http://www.bio-rad.com/webroot/web/pdf/ Isr/literature/Bulletin_6029.pdf. Accessed January 29, 2015. ${ }^{2}$

Abbreviations: nd, not detectable; Ctrl, control; RA, rheumatoid arthritis; LPS, lipopolysaccharide; PHA, Phaseolus vulgaris; a-PVA-SPION, amino-polyvinyl alcohol coated superparamagnetic iron oxide nanoparticles. 
Table S3 Influence of a-PVA-SPION on the concentration of secreted cytokines in whole blood samples obtained from HD

\begin{tabular}{|c|c|c|c|c|c|c|c|c|}
\hline Cytokine & Ctrl & LPS & PHA & $\begin{array}{l}\text { a-PVA-SPION } \\
\text { I } \mu \mathrm{g} / \mathrm{mL}\end{array}$ & $\begin{array}{l}\text { a-PVA-SPION } \\
10 \mu \mathrm{g} / \mathrm{mL}\end{array}$ & $\begin{array}{l}\text { a-PVA-SPION } \\
100 \mu \mathrm{g} / \mathrm{mL}\end{array}$ & $\begin{array}{l}\text { a-PVA-SPION } \\
\text { I,000 } \mu \mathrm{g} / \mathrm{mL}\end{array}$ & $\begin{array}{l}\text { Norm-serum- } \\
\text { level* }\end{array}$ \\
\hline IL Ira [pg/mL] & 48 & 971 & 1,095 & 241 & 333 & 603 & 371 & 133 \\
\hline $\mathrm{ILI} \beta[\mathrm{pg} / \mathrm{mL}]$ & 2 & 816 & 528 & 6 & 881 & 2,117 & 3,233 & 3 \\
\hline IL2 [pg/mL] & nd & nd & nd & nd & nd & nd & nd & I \\
\hline IL4 [pg/mL] & 3 & 15 & 20 & 4 & 19 & 21 & 20 & 3 \\
\hline IL5 [pg/mL] & nd & nd & nd & nd & nd & nd & nd & 4 \\
\hline IL6 [pg/mL] & 5 & 30,184 & 23,901 & 165 & 14,755 & 30,615 & 22,398 & 5 \\
\hline IL7 [pg/mL] & nd & nd & nd & nd & nd & nd & nd & 21 \\
\hline IL8 [pg/mL] & 110 & $|5,26|$ & 14,485 & 731 & 19,613 & 18,145 & 15,709 & 4 \\
\hline IL9 [pg/mL] & 161 & 225 & 327 & 198 & 237 & 290 & 317 & 12 \\
\hline ILIO [pg/mL] & 5 & 600 & 497 & 6 & 62 & 80 & 203 & 4 \\
\hline $\mathrm{IL} / 2[\mathrm{pg} / \mathrm{mL}]$ & 24 & 84 & 79 & 30 & 57 & 47 & 84 & 16 \\
\hline $\mathrm{ILI} 3[\mathrm{pg} / \mathrm{mL}]$ & nd & nd & nd & nd & nd & nd & nd & 4 \\
\hline ILI5 [pg/mL] & nd & nd & nd & nd & nd & nd & nd & I \\
\hline ILI7 [pg/mL] & 53 & 144 & 299 & 51 & 148 & 143 & 156 & 21 \\
\hline Eotaxin $[\mathrm{pg} / \mathrm{mL}]$ & 66 & 91 & 93 & 80 & 85 & 98 & 82 & 31 \\
\hline FGF basic $[\mathrm{pg} / \mathrm{mL}]$ & 6 & 36 & 28 & 27 & 29 & 23 & 30 & 7 \\
\hline G-CSF $[p g / m L]$ & 47 & 371 & 256 & 27 & 386 & 538 & 1,672 & 52 \\
\hline GM-CSF [pg/mL] & 137 & 198 & 199 & 103 & 134 & 159 & 112 & 6 \\
\hline IFN- $\gamma[\mathrm{pg} / \mathrm{mL}]$ & 546 & 3,291 & 2,710 & 1,165 & 799 & 2,487 & 1,729 & 77 \\
\hline MCPI $[\mathrm{pg} / \mathrm{mL}]$ & 111 & 2,305 & 4,509 & 409 & 6,419 & 7,188 & 6,121 & 16 \\
\hline MIPIa [pg/mL] & 17 & $7,24 I$ & 11,755 & 51 & 2,257 & 7,059 & 5,808 & 7 \\
\hline MIPIb [pg/mL] & 214 & 4,073 & 16,550 & 786 & $|1,7| 8$ & 16,665 & 12,236 & 35 \\
\hline IPIO [pg/mL] & 551 & 24,929 & 26,849 & 5,744 & 890 & 742 & 689 & I,388 \\
\hline PGDF [pg/mL] & 1,098 & 2,310 & 2,828 & $\mathrm{I}, \mathrm{I} 78$ & 3,100 & 3,335 & 2,319 & I,57| \\
\hline RANTES $[\mathrm{pg} / \mathrm{mL}]$ & 6,267 & 10,547 & 11,419 & 8,913 & 10,289 & 10,928 & 9,433 & $204^{2}$ \\
\hline $\mathrm{TNF} \alpha[\mathrm{pg} / \mathrm{mL}]$ & 61 & 4,863 & 3,186 & 75 & $\mathrm{I}, 083$ & 1,315 & 220 & 35 \\
\hline VEGF $[\mathrm{pg} / \mathrm{mL}]$ & 32 & 136 & 191 & 59 & 76 & 64 & 125 & 11 \\
\hline
\end{tabular}

Notes: Supernatants were collected from whole blood survival assays (blood samples obtained from healthy donors) after 20 hours with or without SPION treatment and analyzed by multiplex suspension array. Supernatants from four HD were analyzed: median values are shown for the controls (LPS, PHA) and the different SPION concentrations $(\mathrm{I}-\mathrm{I}, 000 \mu \mathrm{g} / \mathrm{mL})$. *Adapted from Up-regulation of cytokines and chemokines predates the onset of rheumatoid arthritis, Arthritis \& Rheumatism, John Wiley and Sons. Copyright (C) 2010 by the American College of Rheumatology.! \&Copyright @ 2010 . Bio-Rad Laboratories, Inc. Adapted from Chapman P, Reyes C, Gupta V. Normal Physiological Levels of Human Cytokines Using Bio-Plex Pro ${ }^{\mathrm{TM}}$ Cytokine Assays. Bio-Rad Tech Note. 2010;6029. Available from: http://www.bio-rad.com/webroot/web/pdf/ Isr/literature/Bulletin_6029.pdf. Accessed January 29, 2015. ${ }^{2}$

Abbreviations: nd, not detectable; Ctrl, control; HD, healthy donors; LPS, lipopolysaccharide; PHA, Phaseolus vulgaris; a-PVA-SPION, amino-polyvinyl alcohol coated superparamagnetic iron oxide nanoparticles.

\section{References}

1. Kokkonen H, Soderstrom I, Rocklov J, Hallmans G, Lejon K, Rantapaa Dahlqvist S. Up-regulation of cytokines and chemokines predates the onset of rheumatoid arthritis. Arthritis Rheum. 2010;62(2):383-391.

2. Chapman P, Reyes C, Gupta V. Normal Physiological Levels of Human Cytokines Using Bio-Plex Pro ${ }^{\mathrm{TM}}$ Cytokine Assays. Bio-Rad Tech Note. 2010;6029. Available from: http://www.bio-rad.com/webroot/web/pdf/ 1sr/literature/Bulletin_6029.pdf. Accessed January 29, 2015.

International Journal of Nanomedicine

\section{Publish your work in this journal}

The International Journal of Nanomedicine is an international, peerreviewed journal focusing on the application of nanotechnology in diagnostics, therapeutics, and drug delivery systems throughout the biomedical field. This journal is indexed on PubMed Central, MedLine, CAS, SciSearch ${ }^{\circledR}$, Current Contents ${ }^{\circledR} /$ Clinical Medicine,

Journal Citation Reports/Science Edition, EMBase, Scopus and the Elsevier Bibliographic databases. The manuscript management system is completely online and includes a very quick and fair peer-review system, which is all easy to use. Visit http://www.dovepress.com/ testimonials.php to read real quotes from published authors. 